Article

\title{
The Use of Bilberry Leaves (Vaccinium myrtillus L.) as an Efficient Adsorbent for Cationic Dye Removal from Aqueous Solutions
}

\author{
Giannin Mosoarca *(D, Cosmin Vancea *, Simona Popa *, Mircea Dan and Sorina Boran
}

Citation: Mosoarca, G.; Vancea, C.; Popa, S.; Dan, M.; Boran, S. The Use of Bilberry Leaves (Vaccinium myrtillus L.) as an Efficient Adsorbent for Cationic Dye Removal from

Aqueous Solutions. Polymers 2022, 14 978. https://doi.org/10.3390/ polym14050978

Academic Editor: Luis Alves

Received: 7 February 2022

Accepted: 23 February 2022

Published: 28 February 2022

Publisher's Note: MDPI stays neutral with regard to jurisdictional claims in published maps and institutional affiliations.

Copyright: (C) 2022 by the authors. Licensee MDPI, Basel, Switzerland. This article is an open access article distributed under the terms and conditions of the Creative Commons Attribution (CC BY) license (https:// creativecommons.org/licenses/by/ $4.0 /$ )
Faculty of Industrial Chemistry and Environmental Engineering, Politehnica University Timisoara, Bd. V. Parvan, No. 6, 300223 Timisoara, Romania; mircea.dan@upt.ro (M.D.); sorina.boran@upt.ro (S.B.)

* Correspondence: giannin.mosoarca@upt.ro (G.M.); cosmin.vancea@upt.ro (C.V.); simona.popa@upt.ro (S.P.); Tel.: +40-256-404-185 (G.M.); +40-256-404-194 (C.V.); +40-256-404-212 (S.P.)

\begin{abstract}
In this study, a new lignocellulosic bioadsorbent, bilberry (Vaccinium myrtillus L.) leaves powder, was used to remove the methylene blue dye from aqueous solutions. The characterization of the adsorbent was performed by FTIR, SEM and color analysis. The influence of $\mathrm{pH}$, contact time, adsorbent dose, initial dye concentration, temperature and ionic strength on the adsorption process were followed. Equilibrium, kinetic, and thermodynamic studies were conducted in order to understand the adsorption process mechanism. Process optimization was performed using the Taguchi method. Sips isotherm and general order kinetic model characterize the adsorption process. The maximum adsorption capacity, $200.4\left(\mathrm{mg} \mathrm{g}^{-1}\right)$, was better compared with other similar bioadsorbents. Thermodynamic parameters indicated that the adsorption process is spontaneous, favorable and endothermic and also that physisorption is involved in the process. The factor with the highest influence on the dye removal process was $\mathrm{pH}$, followed by contact time, temperature, adsorbent dose, ionic strength and initial dye concentration. The obtained results revealed that the bioadsorbent material based on bilberry (Vaccinium myrtillus L.) leaves is highly efficient for cationic dyes removal from aqueous solutions.
\end{abstract}

Keywords: adsorption; lignocellulosic material; equilibrium; kinetics; thermodynamic; Taguchi optimization

\section{Introduction}

Nowadays, dyes have many applications in everyday life and are widely used in various industries such as textile, pigments, plastics, printing, leather, food, rubber, paper and cosmetics [1-7]. Most of these dyes end up in wastewater which, without proper treatment, can cause serious environmental problems [5,7-11].

Cationic dyes are an important category of dyes used in industry, some of which having high toxicity. More than $10 \%$ of cationic dyes produced annually reach in wastewaters [12,13]. Methylene blue is a cationic dye commonly used in the textile industry, especially for dyeing cotton, silk and wool $[1,2,14,15]$. It is used in medical practice for treatment of methaemoglobinemia and cyanide poisoning and can also play the role of staining agent in diagnostic examinations $[2,16]$. It may have a harmful effect on human health leading to eye irritation, vomiting, diarrhea, tachycardia and respiratory problem [15-17].

Adsorption is a commonly used method of removing dyes from wastewater because it has high efficiency, selectivity and flexibility, design simplicity, ease of operation and low economic costs. Another major advantage of this process is the wide variety of adsorbent materials available. The identification and use of new adsorbent biomaterials that are easily available in nature in large quantities leads to a pronounced decrease in costs and represent a topical issue $[16,18-22]$.

Due to their chemical composition, natural plant-based materials and agricultural waste have been successfully tested for the adsorption of various organic and inorganic 
pollutants [23-25]. Plant leaves contain cellulose, lignin, polyphenolics, plant pigments and protein that can provide active adsorption sites for dye retention [26-28]. In addition, these materials are available in large quantities and do not require additional preliminary stages of treatment and activation. Thus, the costs are reduced and most of the time the regeneration of these adsorbents is not necessary $[29,30]$.

Bilberry (Vaccinium myrtillus L.) is a low-growing shrub native to Europe, wide-spread in mountainous and sub-montane areas [31]. It is found all over the world, especially in temperate and sub-arctic regions [32]. Dark purple fruits can be eaten fresh or processed and contain many vitamins and minerals. They also contain an impressive amount of antioxidants and phenolic compounds, necessary for maintaining health, and which give them antioxidant, antiviral and antibacterial properties [33-36]. Not only the fruits are beneficial to human health but also various parts of the plant, which have been used in traditional medicine in Europe for over 1000 years [32,33,37].

The aim of this study was to remove methylene blue cationic dye from aqueous solutions using the new bioadsorbent material obtained from bilberry (Vaccinium myrtillus L.) leaves. After characterizing the bioadsorbent, using FTIR, SEM and color analysis, the influence of $\mathrm{pH}$, adsorbent dose, ionic strength, contact time, initial dye concentration and temperature on the adsorption process were followed. Equilibrium, kinetics, and thermodynamics studies were also performed.

\section{Materials and Methods}

The bilberry (Vaccinium myrtillus L.) dried leaves were purchased from a manufacturer who processes medicinal plants, StefMar (Ramnicu Valcea, Romania). The leaves were washed with distilled water, dried in an air oven at $105{ }^{\circ} \mathrm{C}$ for $24 \mathrm{~h}$ and then ground electrically. The obtained powder material was passed through a $2 \mathrm{~mm}$ sieve.

In order to characterize the bioadsorbent material, before and after dye adsorption, SEM analysis and FTIR spectroscopy were carried out using a Quanta FEG 250 (FEI, Eindhoven, The Netherlands) scanning electron microscope (1600 $\times$ magnitude) and a Shimadzu Prestige-21 FTIR (Shimadzu, Kyoto, Japan) spectrophotometer. The colorimetric analysis was recorded for the D65 (natural light) under $10^{\circ}$ observer angle, using a CaryVarian 300 Bio UV-VIS colorimeter (Varian Inc., Mulgrave, Australia) with integrating sphere and a Spectralon standard. All CIEL $L^{*} a^{*} b^{*}$ color data were expressed by $L^{*}, a^{*}, b^{*}$ coordinates, where $L^{*}$ corresponds to lightness; $a^{*}$ corresponds to the transition from green $\left(-a^{*}\right)$ to red $\left(+a^{*}\right)$; and $b^{*}$ corresponds to the transition from blue $\left(-b^{*}\right)$ to yellow $\left(+b^{*}\right)$. The $\mathrm{pH}$ at which the net charge of the adsorbent surface is zero, (PZC), was determined using the solid addition method [38].

The adsorption experiments were performed at a constant stirring intensity provided by a shaker. Three independent replicates were made for each experiment. The $\mathrm{pH}$ adjustment $0.1 \mathrm{~N} \mathrm{NaOH}$ and $\mathrm{HCl}$ solutions were used. The influence of ionic strength was follow using $\mathrm{NaCl}$ as background electrolyte. The methylene blue concentration was measured with a Specord 200 PLUS UV-VIS (Analytik Jena, Jena, Germany) spectrophotometer at a wavelength of $664 \mathrm{~nm}$.

The dye amounts adsorbed at equilibrium $\left(q_{e}\right)$ and the methylene blue removal percentage $R(\%)$ were calculated with Equations (1) and (2) [18,38]:

$$
\begin{gathered}
q_{e}=\frac{\left(C_{0}-C_{e}\right) \times V}{m}, \\
R(\%)=\frac{\left(C_{0}-C_{e}\right)}{C_{0}} \times 100,
\end{gathered}
$$

where: $C_{0}$ is the initial dye concentration; $C_{e}$ is the dye equilibrium concentration; $V$ is the solution volume and $m$ is the mass of bioadsorbent. 
Non-linear equations of pseudo-first order, pseudo-second order, Elovich, general order and Avrami kinetic models were used to analyze the adsorption kinetics. The equations are described below:

$$
\begin{aligned}
& \text { Pseudo }- \text { first }- \text { order model equation : } q_{t}=q_{e}\left(1-\exp ^{-k_{1} \times t}\right), \\
& \text { Pseudo }- \text { sec ond }- \text { order model equation : } q_{t}=\frac{k_{2} \times t \times q_{e}^{2}}{1+k_{2} \times t \times q_{e}}, \\
& \text { Elovich model equation : } q_{t}=\frac{1}{a} \ln (1+a \times b \times t), \\
& \text { General order model equation : } q_{t}=q_{n}-\frac{q_{n}}{\left[k_{n} \times\left(q_{n}\right)^{n-1} \times t \times(n-1)+1\right]^{1 / 1-n}}, \\
& \text { Avrami model equation : } q_{t}=q_{A V}\left[1-\exp \left(-k_{A V} \times t\right)^{n_{A V}}\right],
\end{aligned}
$$

where: $q_{t}$ is the crystal violet amount adsorbed at time $t ; k_{1}, k_{2}, k_{n}$ and $k_{A V}$ are the rate constants of pseudo-first-order, pseudo-second-order, general order and Avrami kinetic models; $q_{e}, q_{n}$ and $q_{A V}$ are the theoretical values for the adsorption capacity; $a$ is the desorption constant of Elovich model; $b$ is the initial velocity; $n$ is the general order exponent and $n_{A V}$ is a fractional exponent [18,39-43].

Non-linear equations of Langmuir, Freundlich, Temkin, Sips and Redlich-Peterson isotherms were used to describe the adsorption equilibrium. The corresponding equations are as follows:

$$
\begin{aligned}
& \text { Langmuir isotherm equation : } q_{e}=\frac{q_{m} \times K_{L} \times C_{e}}{1+K_{L} \times C_{e}}, \\
& \text { Freundlich isotherm equation : } q_{e}=K_{F} \times C_{e}^{1 / n_{F}}, \\
& \text { Temkin isotherm equation : } q_{e}=\frac{R \times T}{b} \times \ln \left(K_{T} \times C_{e}\right), \\
& \text { Sips isotherm equation : } q_{e}=\frac{Q_{s a t} \times K_{S} \times C_{e}^{n}}{1+K_{S} \times C_{e}^{n}}, \\
& \text { Redlich - Peterson isotherm equation : } q_{e}=\frac{K_{R P} \times C_{e}}{1+a_{R P} \times C_{e}^{\beta_{R P}}},
\end{aligned}
$$

where: $q_{m}$ and $Q_{s a t}$ are the maximum absorption capacities; $K_{L}, K_{F}, K_{T}, K_{S}$ and $K_{R P}$ are the Langmuir, Freundlich, Temkin, Sips and Redlich-Peterson isotherms constants; $1 / n_{F}$ is an empirical constant indicating the intensity of adsorption; $R$ is the universal gas constant; $T$ is the absolute temperature; $b$ is Temkin constant which related to the adsorption heat; $n$ is Sips isotherm exponent; $a_{R P}$ is Redlich-Peterson isotherm constant and $\beta_{R P}$ is Redlich-Peterson exponent which can vary between 0 and 1 [18,39-43].

In order to establish the proper isotherm and kinetic models values of determination coefficient $\left(R^{2}\right)$, sum of square error (SSE), chi-square $\left(\chi^{2}\right)$ and average relative error (ARE) were calculated [43]. The criterion for their applicability was the higher value for $R^{2}$ and the lower values for $S S E, \chi^{2}$, and $A R E$ was the criterion for establishing the best model.

$$
\begin{gathered}
R^{2}=1-\frac{\sum_{i=1}^{n}\left(y_{i, \exp }-y_{i, \text { mod }}\right)^{2}}{\sum_{i=1}^{n}\left(y_{i, \exp }-\overline{y_{i, e x p}}\right)^{2}}, \\
S S E=\sum_{i=1}^{n}\left(y_{i, \exp }-y_{i, \text { mod }}\right)^{2}, \\
\chi^{2}=\sum_{i=1}^{n} \frac{\left(y_{i, \exp }-y_{i, \text { mod }}\right)^{2}}{y_{i, \text { mod }}},
\end{gathered}
$$




$$
A R E=\frac{100}{n} \sum_{i=1}^{n}\left|\frac{y_{i, e x p}-y_{i, \bmod }}{y_{i, \bmod }}\right|,
$$

where: $y_{i, \exp }$ is the experimental value; $y_{i, \text { mod }}$ is the modeled value; $\overline{y_{i, \exp }}$ is the mean values and $n$ is the total amount of information.

The values for Gibbs free energy change, enthalpy change and entropy change were calculated (at 278, 287, 297, 303 and $311 \mathrm{~K}$ ) using the Equations (17) and (18) [18,40]:

$$
\begin{gathered}
\Delta G^{0}=-R T \ln K_{L}, \\
\ln K_{L}=\frac{\Delta S^{0}}{R}-\frac{\Delta H^{0}}{R T},
\end{gathered}
$$

where: $R$ is the universal gas constant; $K_{L}$ is the Langmuir constant and $T$ is the absolute temperature.

The optimum dye removal conditions were determined using the Taguchi methods, applying the L25 orthogonal array with six factor at five levels (Table 1). The effect of the controllable factors on methylene blue removal efficiency was evaluated by the signal/noise ratio $(\mathrm{S} / \mathrm{N})$ analysis choosing the "larger is the better" option $[44,45]$. The results of the Taguchi method were evaluated by analysis of variance analysis (ANOVA) with which established the percentage contribution of each factor on the dye removal efficiency. All calculations were performed with the Minitab 19 Software (version 19.1.1, Minitab LLC, State College, PA, USA).

Table 1. Controllable factors and their levels used in L25 orthogonal array.

\begin{tabular}{cccccc}
\hline Factor & Level 1 & Level 2 & Level 3 & Level 4 & Level 5 \\
\hline $\mathrm{pH}$ & 2 & 4 & 6 & 8 & 10 \\
Time $(\mathrm{min})$ & 5 & 15 & 30 & 40 & 50 \\
Adsorbent dose $\left(\mathrm{mg} \cdot \mathrm{L}^{-1}\right)$ & 1 & 2 & 3 & 4 & 5 \\
Initial dye concentration $\left(\mathrm{mg} \cdot \mathrm{L}^{-1}\right)$ & 25 & 50 & 100 & 150 & 200 \\
Temperature $(\mathrm{K})$ & 278 & 287 & 297 & 305 & 311 \\
Ionic strength $\left(\mathrm{mol} \mathrm{L}^{-1}\right)$ & 0 & 0.05 & 0.10 & 0.15 & 0.20 \\
\hline
\end{tabular}

Three regenerating agents were used in the desorption studies $(0.1 \mathrm{~N} \mathrm{HCl}$, distilled water and $0.1 \mathrm{~N} \mathrm{NaOH}$ ). The experiments were performed at a constant stirring rate, for $2 \mathrm{~h}$. The methylene blue desorption percentage $D(\%)$ was determined with the equation:

$$
D(\%)=\frac{m_{d}}{m_{a}} \times 100
$$

where: $m_{d}$ is the dye amount liberated by the regenerating agent and $m_{a}$ is the dye amount adsorbed on the adsorbent material.

\section{Results and Discussion}

\subsection{Bioadsorbent Characterization}

The FTIR spectra (Figure 1), before and after adsorption process, reveal that cellulose, hemicellulose and lignin are the main components of the bioadsorbent material. The specific peaks that indicate the functional groups presence of this components are as follow: $3610 \mathrm{~cm}^{-1}$ can be attributed to the $-\mathrm{OH}$ stretch, free hydroxyl [46], $3300 \mathrm{~cm}^{-1}$ can be assigned the $-\mathrm{OH}$ stretching vibrations of cellulose, lignin or hemicellulose present in lignocellulosic biomasses [47], $2938 \mathrm{~cm}^{-1}$ correspond to $\mathrm{CH}_{2}$ stretching vibration [48,49], $1647 \mathrm{~cm}^{-1}$ indicate $-\mathrm{C}=\mathrm{O}$ stretching characteristic of lignin or hemicellulose $[50,51], 1550 \mathrm{~cm}^{-1} \mathrm{can}$ be attributed to the amide II groups [52,53], $1422 \mathrm{~cm}^{-1}$ corresponding to -C-H deformation in lignin [54,55], $1282 \mathrm{~cm}^{-1}$ can be attributed to the $\mathrm{CH}$ deformation in cellulose I and cellulose II [56], $1057 \mathrm{~cm}^{-1}$ can be assigned to C-O-C stretching of cellulose [27,39], $698 \mathrm{~cm}^{-1}$ were mainly due aromatic out of plane $\mathrm{C}-\mathrm{H}$ bending vibrations $[57,58], 542 \mathrm{~cm}^{-1}$ 
can be attributed $\mathrm{C}-\mathrm{H}$ bend [59]. After adsorption, FTIR spectra shows some changes and three methylene blue characteristic peak appear that indicate the presence of dye at adsorbent surface: $3443 \mathrm{~cm}^{-1}$ corresponds to $-\mathrm{NH} /-\mathrm{OH}$ overlapped stretching vibration [60], $1392 \mathrm{~cm}^{-1}$ can be attributed to the vibration of $\mathrm{C}-\mathrm{N}$ in the $-\mathrm{N}\left(\mathrm{CH}_{3}\right)^{2+}$ group and $1326 \mathrm{~cm}^{-1}$ can be associated with the $-\mathrm{CH}_{3}$ group $[15,61]$.

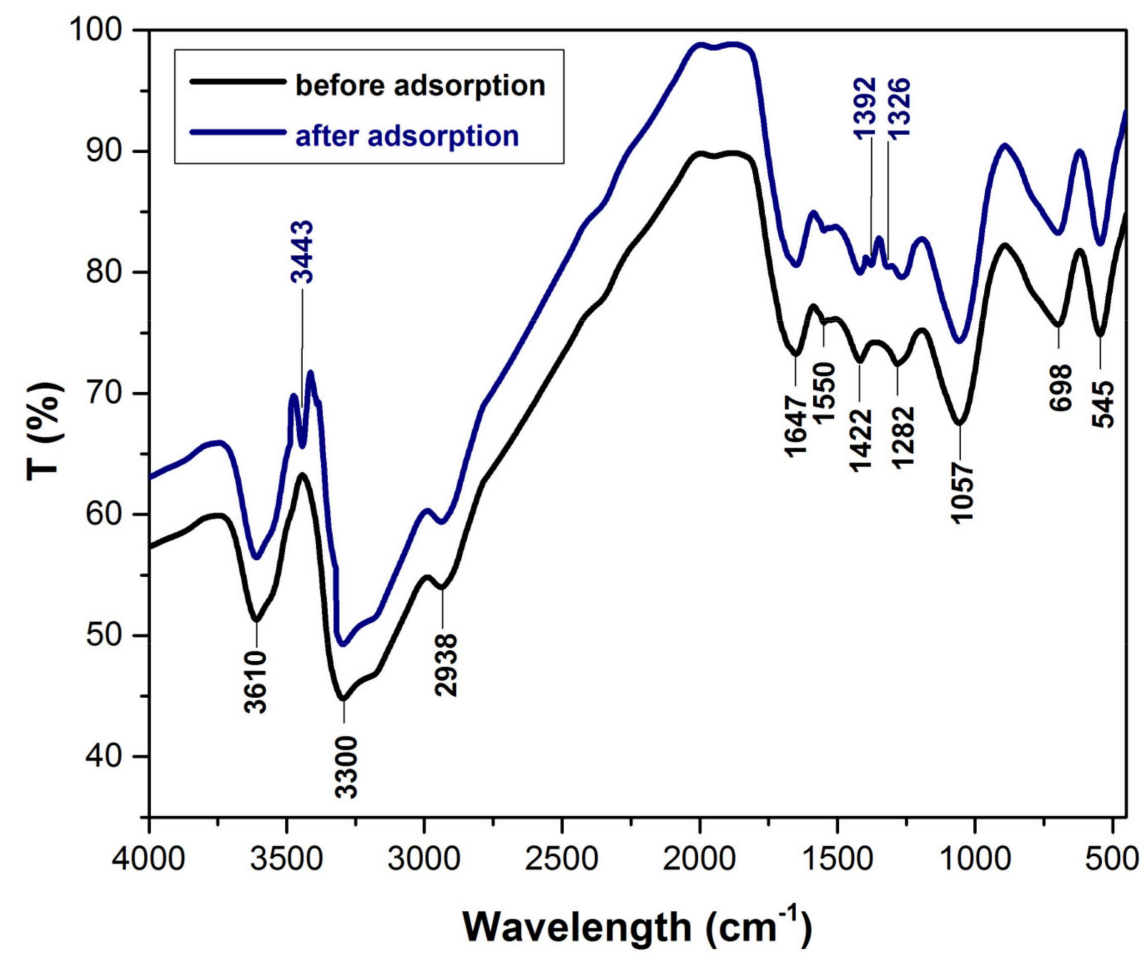

Figure 1. The FTIR spectra (before and after adsorption process) of bioadsorbent obtained from bilberry (Vaccinium myrtillus L.) leaves.

The SEM images of adsorbent material are illustrated in Figure 2. Prior to adsorption (Figure 2a), the surface of the adsorbent is heterogeneous, with many pores, folds and voids of various shapes suggesting a suitable structure for the adsorption of dyes. After adsorption (Figure 2b), the surface becomes more homogeneous and compact, which indicate that dye molecules filled the pores and cavities.

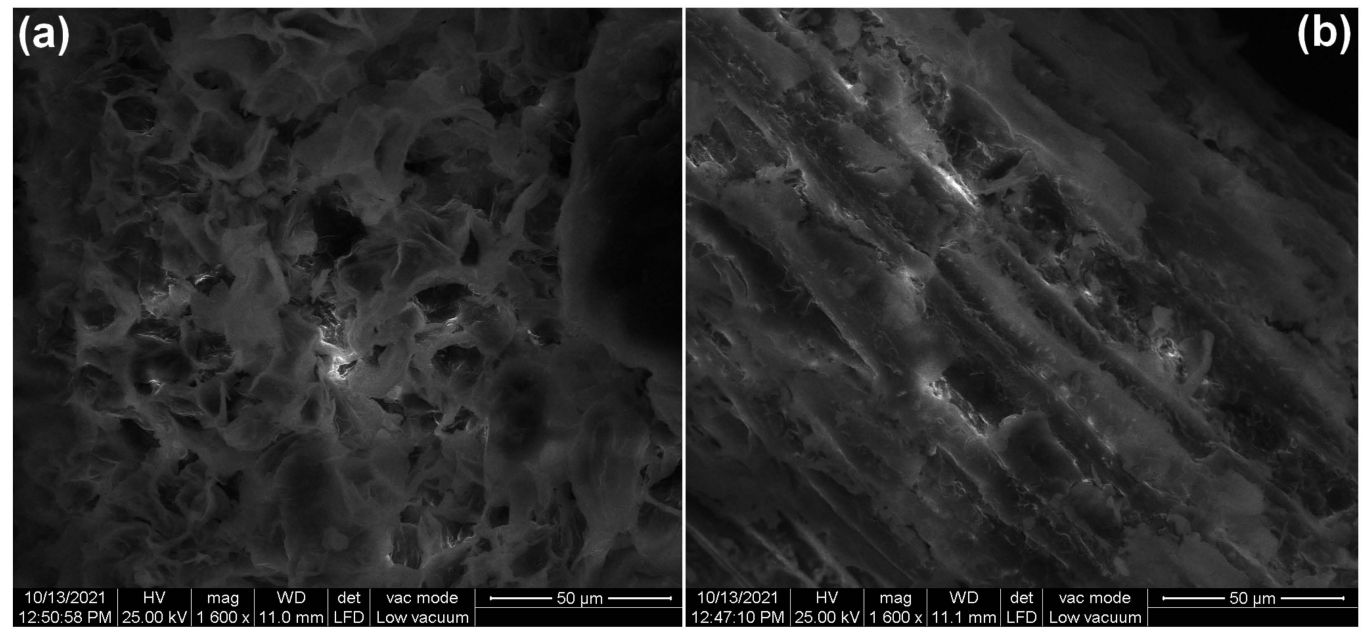

Figure 2. The SEM images of bioadsorbent obtained from bilberry (Vaccinium myrtillus L.) leaves: (a) before adsorption, (b) after adsorption. 
The color of adsorbent materials (the bilberry leaves powder) that were used in the adsorption process of methylene blue was monitored with the CIEL $a^{*} b^{*}$ color parameters (Figure 3). The color of vegetables is primarily given by the pigments in the plant. By drying, the green color of live leaves may diminish, but there will still be a residual color of the vegetable wastes (Figure 3 , point $b$ ).

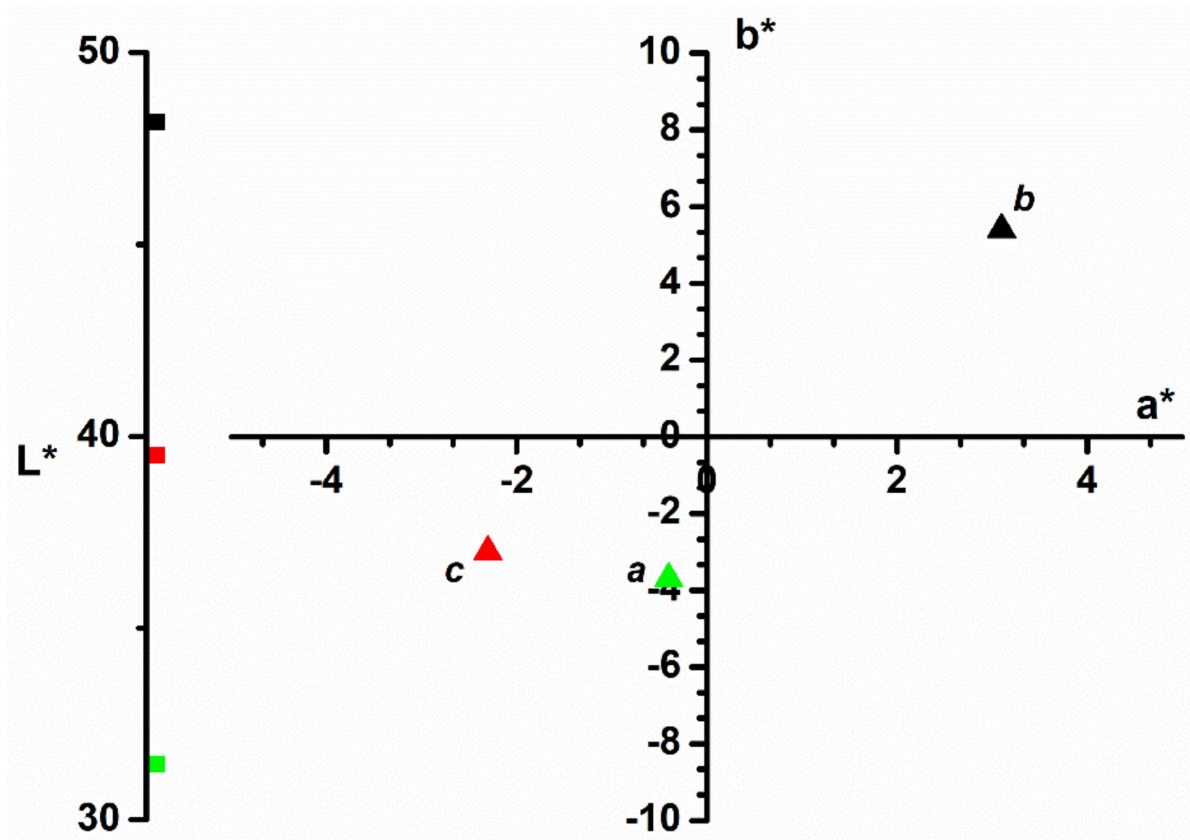

Figure 3. $C I E L^{*} a^{*} b^{*}$ color parameters of: $a$-methylene blue dye; $b$-bilberry leaves before adsorption process; $c$-bilberry leaves after adsorption process.

The color's behavior during the adsorption process reveals that the dye color passes from the solution onto the adsorption material. Although the bilberry leaves' luminosity lowers with approximately 10 units after adsorption, the other $C I E L^{*} a^{*} b^{*}$ color parameters namely $a^{*}$ and $b^{*}$ obviously change. Thus, the $a^{*}$ parameter moves from red to green and the $b^{*}$ parameter from yellow to blue. As a result, the color of the bilberry leaves used as adsorbent will turn from light orange (Figure 3, point $b$ ) to turquoise (Figure 3, point $c$ ), color similar to the methylene blue dye (Figure 3 , point $a$ ). The color parameters show that the adsorbent material changes its color, which confirms the dye adsorption on the material surface.

The point of zero charge (PZC) is a significant and useful parameter that indicates when the adsorbent surface has become positively or negatively charged depending on the $\mathrm{pH}$. According to Figure 4 the determined value for this parameter was 5.12. At $\mathrm{pH}$ value lower than PZC the adsorbent surface is positively charged and at $\mathrm{pH}$ value higher than PZC the adsorbent surface is negatively charged $[16,20,27,38]$.

\subsection{Influence of $p H$ on Dye Adsorption}

The Figure 5 shows the influence of the initial solution $\mathrm{pH}$ on the adsorption capacity and the removal efficiency. Both parameters recorded the lowest values at $\mathrm{pH}=2$. As the initial solution $\mathrm{pH}$ increased, an increase in adsorption capacity and removal efficiency was observed. Thus, on the $\mathrm{pH}$ range $2-6$, the adsorption capacity increased from $13.7\left(\mathrm{mg} \mathrm{g}^{-1}\right)$ to $20.6\left(\mathrm{mg} \mathrm{g}^{-1}\right)$ and the removal efficiency increased from $54.9 \%$ to $82.4 \%$. During the $\mathrm{pH}$ range 6-10, the values of the two parameters remained practically constant. Previous studies have reported the same effects of the initial solution $\mathrm{pH}$ on the adsorption process $[16,62,63]$. The low adsorption rate recorded at the lowest values of $\mathrm{pH}$ (under PZC) can be explained considering that at these $\mathrm{pH}$ values, the adsorbent materials' surface is positively charged generating an electrostatic repulsion of the cationic dye $[1,16]$. At higher 
$\mathrm{pH}$ than PZC, the adsorbent surface became negatively charged and favorable conditions for the adsorption of dye cations occur due to the electrostatic attraction $[16,20,27,38]$.

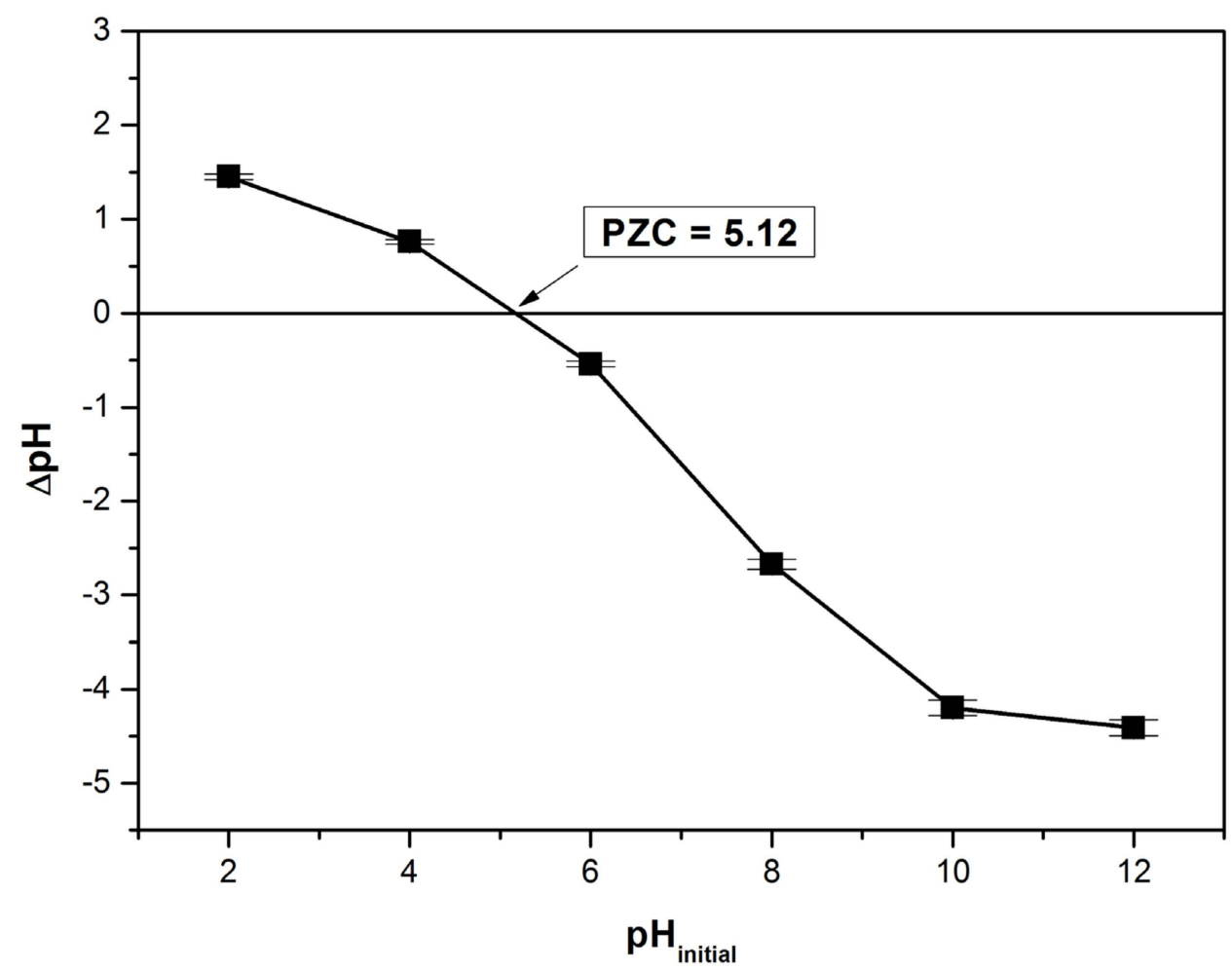

Figure 4. Determination of point of zero charge, PZC, for bioadsorbent material (the solid addition method).

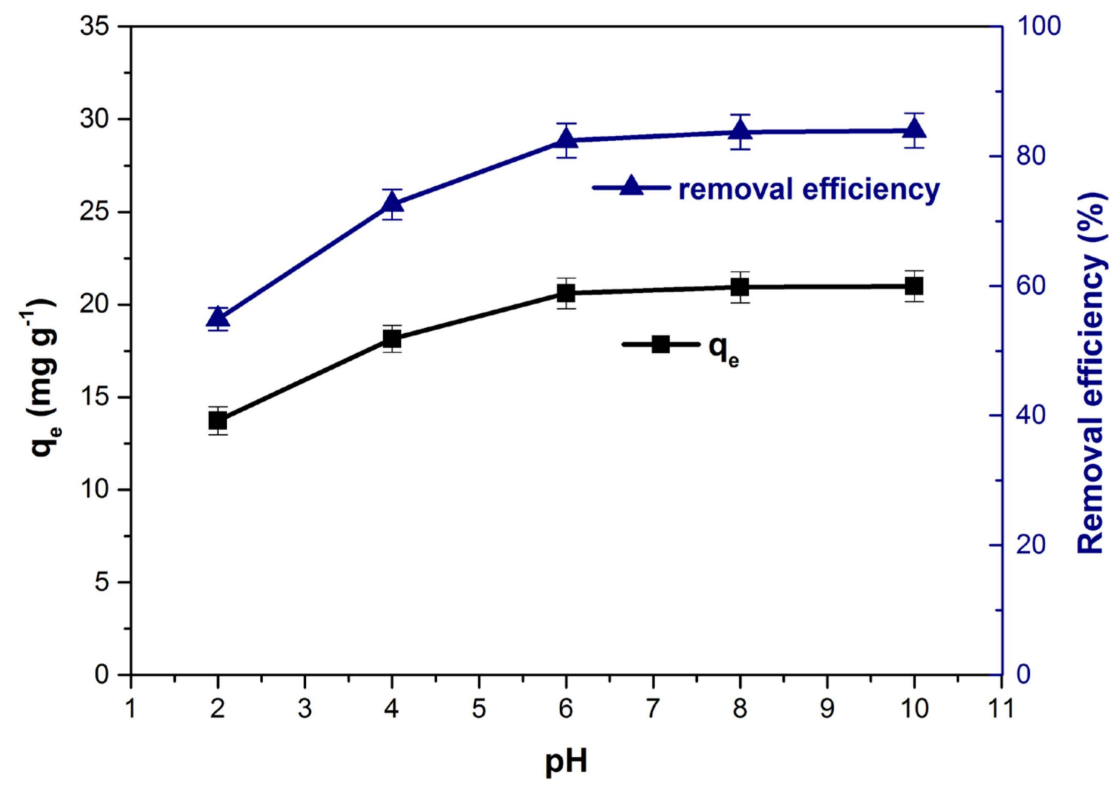

Figure 5. Influence of $\mathrm{pH}$ on adsorption capacity and dye removal efficiency.

\subsection{Influence of Bioadsorbent Dose on Dye Adsorption}

The bioadsorbent dose effect on the adsorption capacity and the dye removal efficiency is depicted in Figure 6. The increase of adsorbent dose from 1 to $5\left(\mathrm{mg} \mathrm{L}^{-1}\right)$, generated an ever-increasing available adsorption sites number which led to an increase in removal efficiency $[1,64,65]$. Meanwhile, many of this adsorption sites remain unsaturated and 
aggregation or agglomeration of adsorbent particle may occur $[23,66]$ and the adsorption capacity decrease from 37.46 to $8.67\left(\mathrm{mg} \mathrm{g}^{-1}\right)$. A similar influence of adsorbent dose on the adsorption capacity and removal efficiency of methylene blue has been previously mentioned by other researchers in their scientific articles [64,65].

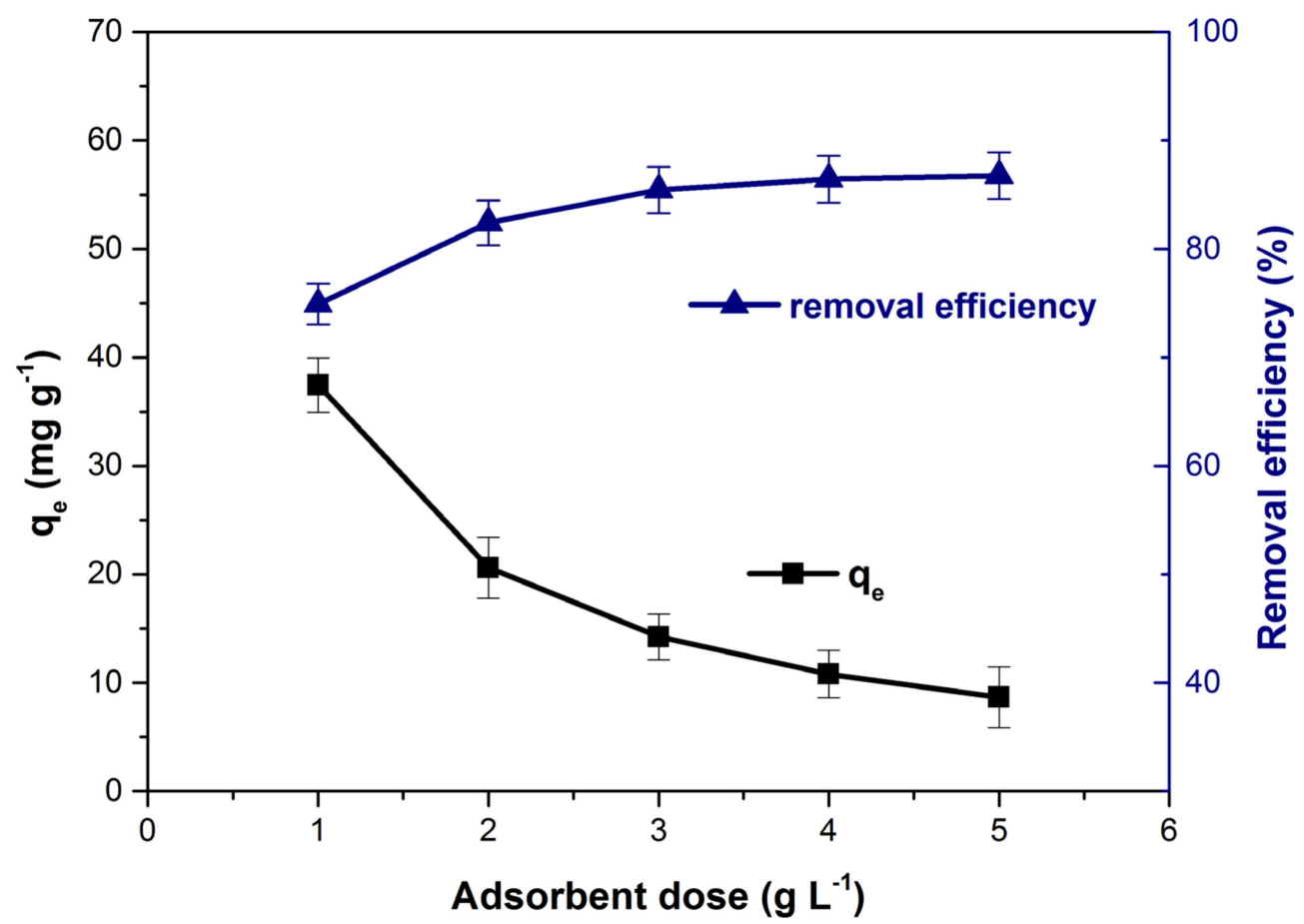

Figure 6. Influence of bioadsorbent dose on adsorption capacity and dye removal efficiency.

\subsection{Influence of Ionic Strength on Dye Adsorption}

The efficiency of the adsorption process can be influenced by the presence of other ions in the solution. In general, colored residual effluents have a high ionic strength due to them. The increase in ionic strength, simulated by the addition of $\mathrm{NaCl}$, led to a decrease in the adsorption capacity and the dye removal efficiency from the solution (Figure 7). The unfavorable effect of ionic strength is due to the competition between dye cations and $\mathrm{Na}^{+}$ ions to occupy the free spaces available for adsorption on the adsorbent material surface and has been observed in other adsorption studies regarding the removal of methylene blue from aqueous solutions $[38,67,68]$.

\subsection{Influence of Contact Time on Dye Adsorption. Process Kinetics}

The variation of adsorption capacity and dye removal efficiency as function of contact time is presented in Figure 8. The values of the monitored parameters increased significantly until reaching equilibrium at a contact time of $40 \mathrm{~min}$.

Initially, the adsorption of the dye was quite fast due to the large number of adsorption sites available on the adsorbent material surface $[1,23,69]$. Over time, they are gradually occupied by dye molecules and the adsorption capacity and methylene blue removal efficiency increase slowly. After the equilibrium was established, almost the entire adsorbent surface of was covered by the dye molecules $[1,24,70]$ and the variation of the both parameters was insignificant. The equilibrium times obtained for methylene blue adsorption on different similar bioadsorbent materials are summarized in Table 2. 


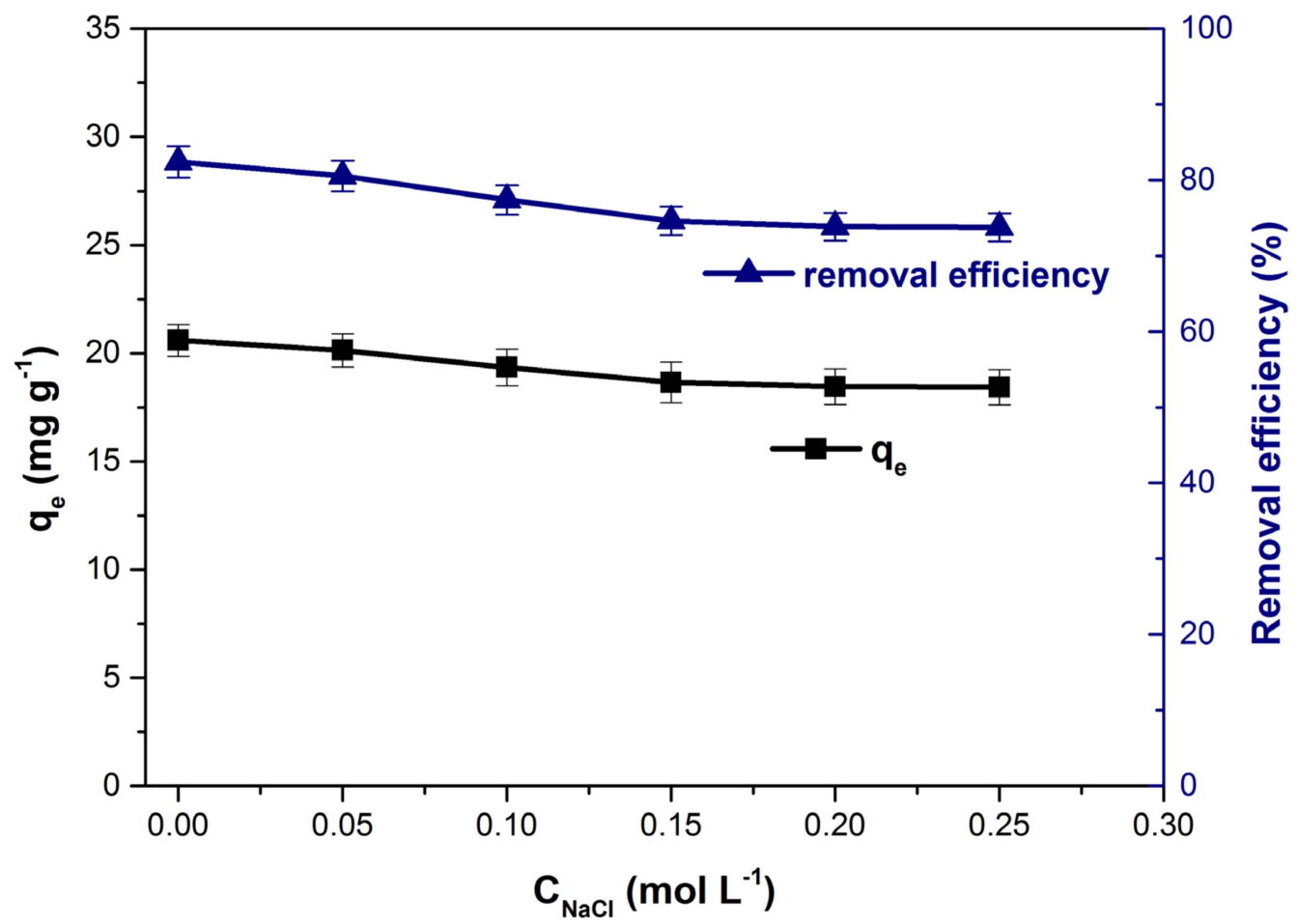

Figure 7. Influence of the ionic strength on adsorption capacity and dye removal efficiency.

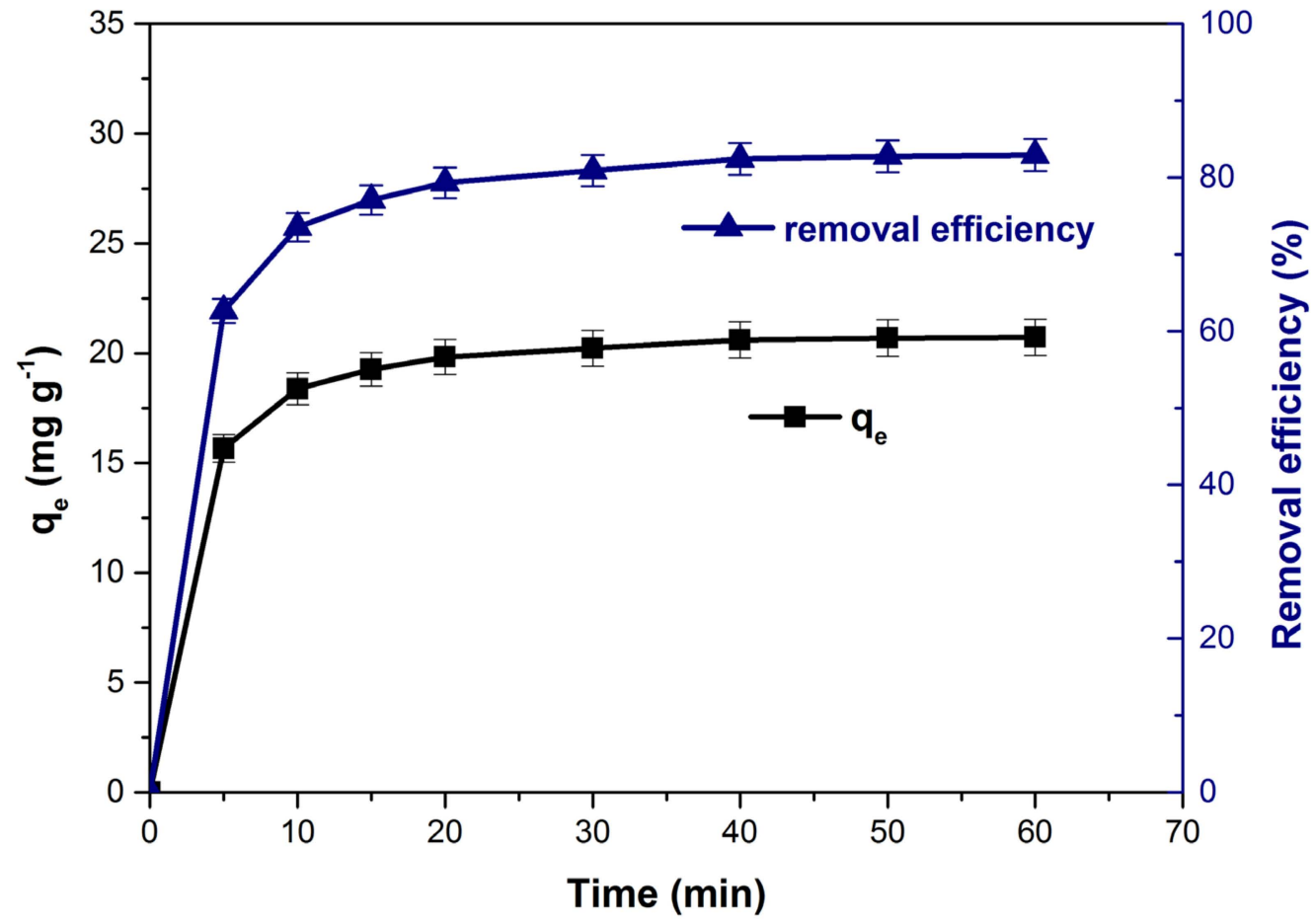

Figure 8. Influence of contact time on adsorption capacity and dye removal efficiency. 
Table 2. The equilibrium times obtained for methylene blue adsorption on different similar bioadsorbent materials.

\begin{tabular}{ccc}
\hline Adsorbent & Equilibrium Time (min) & Reference \\
\hline Humulus japonicas leaves & 20 & {$[24]$} \\
Daucus carota leaves powder & 30 & {$[38]$} \\
Arthrospira platensis biomass & 30 & {$[25]$} \\
Vaccinium myrtillus L. leaves powder & 40 & This study \\
Archidendron jiringa seed shells & 60 & {$[70]$} \\
Typha angustifolia leaves & 60 & {$[23]$} \\
pineapple leaf powder & 60 & {$[29]$} \\
Platanus orientalis leaf powder & 70 & {$[28]$} \\
Phragmites australis biomass & 90 & {$[71]$} \\
nonliving lichen Pseudevernia furfuracea & 90 & {$[72]$} \\
Carica papaya wood & 100 & {$[73]$} \\
Ginkgo biloba leaves & 100 & {$[74]$} \\
phoenix tree's leaves & 150 & {$[30]$} \\
lotus leaf & 150 & {$[62]$} \\
Citrullus colocynthis peels & 180 & {$[1]$} \\
\hline
\end{tabular}

The dye adsorption kinetic was evaluated using the following kinetic models (nonlinear form): pseudo-first order, pseudo-second order, Elovich, general order and Avrami. Analyzing the curves of kinetic models (Figure 9), constants and the corresponding error functions (Table 3) it can be concluded that the most suitable model is general order. This model assumed that the order of an adsorption process must logically follow the same pattern as in a chemical reaction, where the order is experimentally determined instead of being predicted by a given model [75-78]. The coefficient of determination $\left(R^{2}\right)$ values for the general order and the pseudo-second models were very close but the lower values obtained for the error functions (SSE, $\chi^{2}$ and ARE) were the basis for the established conclusion.

\subsection{Influence of Initial Dye Concentration on Dye Adsorption. Adsorption Isotherms}

The increase of the initial concentration, from 25 to $200\left(\mathrm{mg} \mathrm{L}^{-1}\right)$ leads to the appearance of two phenomena that cause the increase of the adsorption capacity from 10.5 to $7.1\left(\mathrm{mg} \mathrm{g}^{-1}\right)$ (Figure 10). First of all, the concentration gradient between the dye solution and the adsorbent material surface increases, therefore the driving force required to overcome the resistance of the mass transfer through the solid/solution interface increases $[1,23,28]$. Secondly, the adsorption process is favored by the increase in the collisions number between the methylene blue molecules and the adsorbent material particles $[1,25]$. At the same time, high concentrations of dye cause the accumulation of molecules on the adsorbent surface and the adsorption sites become saturated which determine a decrease in methylene blue removal efficiency $[23,78,79]$. Similar results have been reported in other studies on the removal of methylene blue from aqueous solutions by adsorption [23,38].

The equilibrium adsorption process was assessed using non-linear isotherms Langmuir, Freundlich, Temkin, Sips and Redlich-Peterson. Following the analysis of the fitted isotherm curves (Figure 11), constants and the corresponding error functions (Table 4) it was found that Sips isotherm best describe the process. This model assumes that the process follows the Freundlich model (diffused adsorption) at low methylene blue concentrations and the Langmuir model (monomolecular adsorption) at high concentrations. Scientific literature reported that Sips isotherm best described other processes of methylene blue adsorption from water [80-82]. 

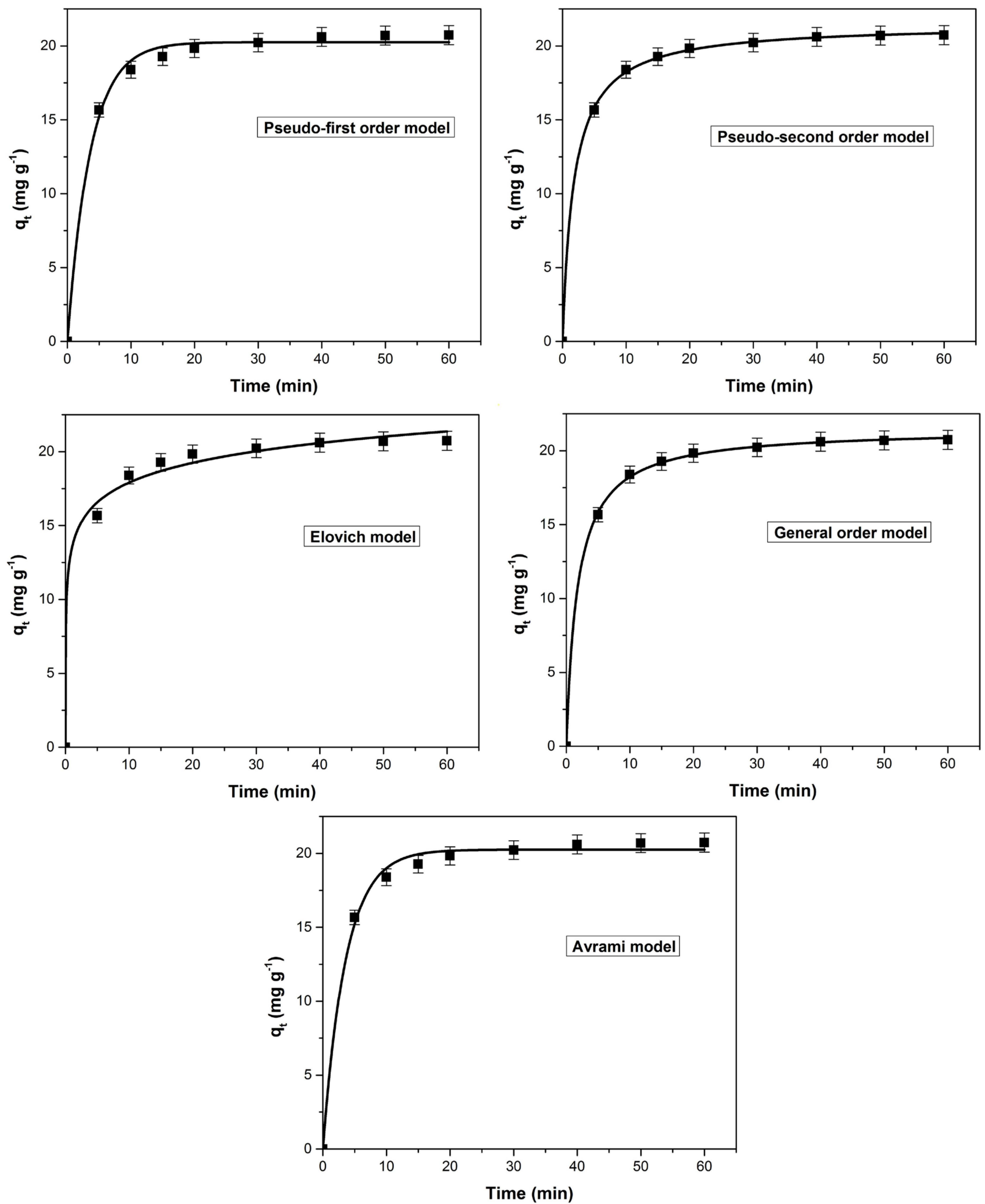

Figure 9. The tested kinetic models (non-linear forms) for the methylene blue adsorption on bioadsorbent obtained from bilberry (Vaccinium myrtillus L.) leaves. 
Table 3. The kinetic models constants and the corresponding error functions.

\begin{tabular}{|c|c|c|}
\hline Kinetic Model & Parameters & Value \\
\hline \multirow{7}{*}{ Pseudo-first order } & $k_{1}\left(\min ^{-1}\right)$ & $0.278 \pm 0.032$ \\
\hline & $q_{e, \text { calc }}\left(\mathrm{mg} \mathrm{g}^{-1}\right)$ & $20.25 \pm 0.31$ \\
\hline & $R^{2}$ & 0.9952 \\
\hline & $\chi^{2}$ & 0.0893 \\
\hline & SSE & 1.69 \\
\hline & $\operatorname{ARE}(\%)$ & 13.07 \\
\hline & $k_{2}\left(\min ^{-1}\right)$ & $0.019 \pm 0.008$ \\
\hline \multirow{5}{*}{ Pseudo-second order } & $q_{e, \text { calc }}\left(\mathrm{g} \mathrm{mg}^{-1} \mathrm{~min}^{-1}\right)$ & $21.48 \pm 0.19$ \\
\hline & $R^{2}$ & 0.9997 \\
\hline & $\chi^{2}$ & 0.0050 \\
\hline & SSE & 0.09 \\
\hline & ARE (\%) & 0.51 \\
\hline \multirow{6}{*}{ Elovich } & $a\left(\mathrm{~g} \mathrm{mg}^{-1}\right)$ & $0.252 \pm 0.047$ \\
\hline & $b\left(\mathrm{mg} \mathrm{g}^{-1} \min ^{-1}\right)$ & $2346 \pm 127$ \\
\hline & $R^{2}$ & 0.9936 \\
\hline & $\chi^{2}$ & 0.1473 \\
\hline & SSE & 2.26 \\
\hline & $\operatorname{ARE}(\%)$ & 13.30 \\
\hline \multirow{7}{*}{ General order } & $k_{N}\left(\min ^{-1}\left(\mathrm{~g} \mathrm{mg}^{-1}\right)^{\mathrm{n}-1}\right)$ & $4.256 \pm 0.245$ \\
\hline & $q_{n}\left(\mathrm{mg} \mathrm{g}^{-1}\right)$ & $21.27 \pm 0.35$ \\
\hline & $n$ & 1.269 \\
\hline & $R^{2}$ & 0.9999 \\
\hline & $\chi^{2}$ & 0.0007 \\
\hline & SSE & 0.01 \\
\hline & ARE (\%) & 0.16 \\
\hline \multirow{7}{*}{ Avrami } & $k_{A V}\left(\min ^{-1}\right)$ & $0.636 \pm 0.054$ \\
\hline & $q_{A V}\left(\mathrm{mg} \mathrm{g}^{-1}\right)$ & $20.25 \pm 0.48$ \\
\hline & $n_{A V}$ & 0.436 \\
\hline & $R^{2}$ & 0.9952 \\
\hline & $x^{2}$ & 0.0888 \\
\hline & SSE & 1.69 \\
\hline & ARE (\%) & 11.10 \\
\hline
\end{tabular}

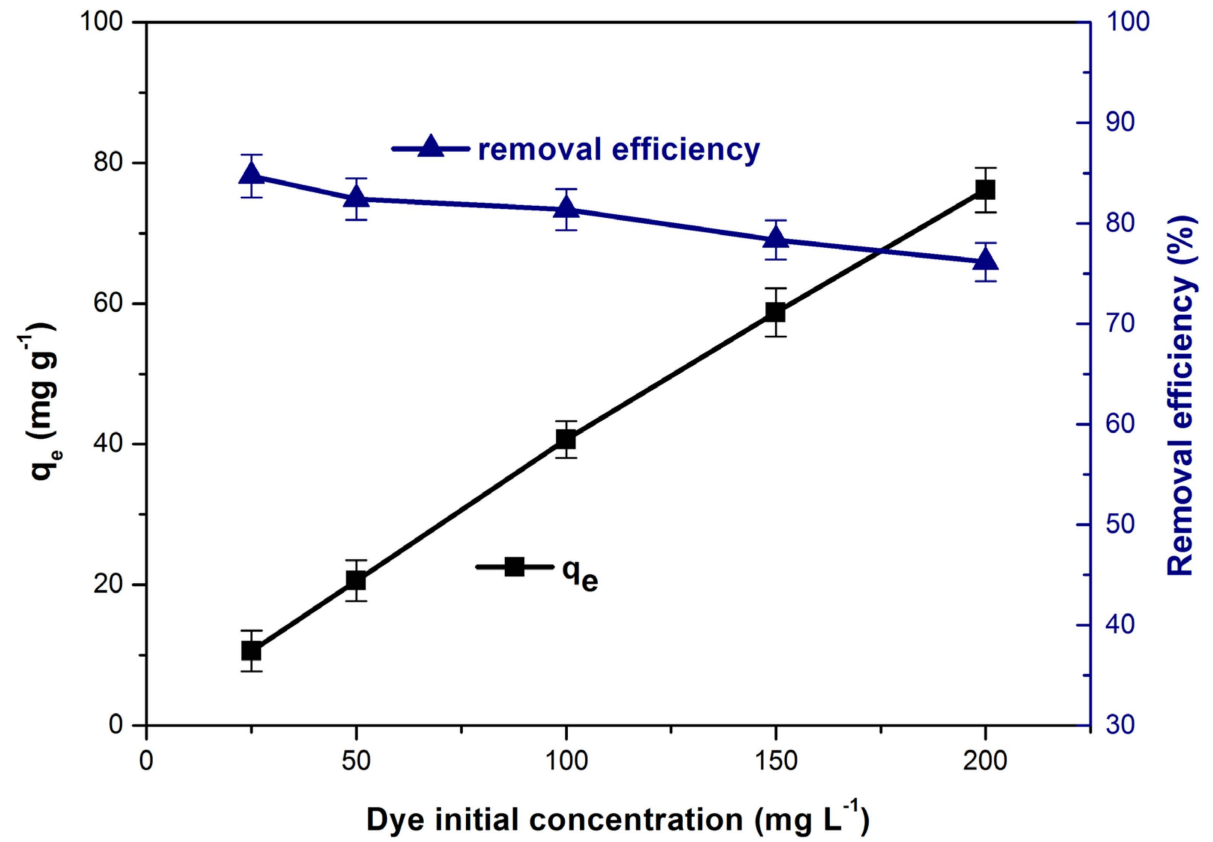

Figure 10. Influence of initial dye concentration on adsorption capacity and dye removal efficiency. 

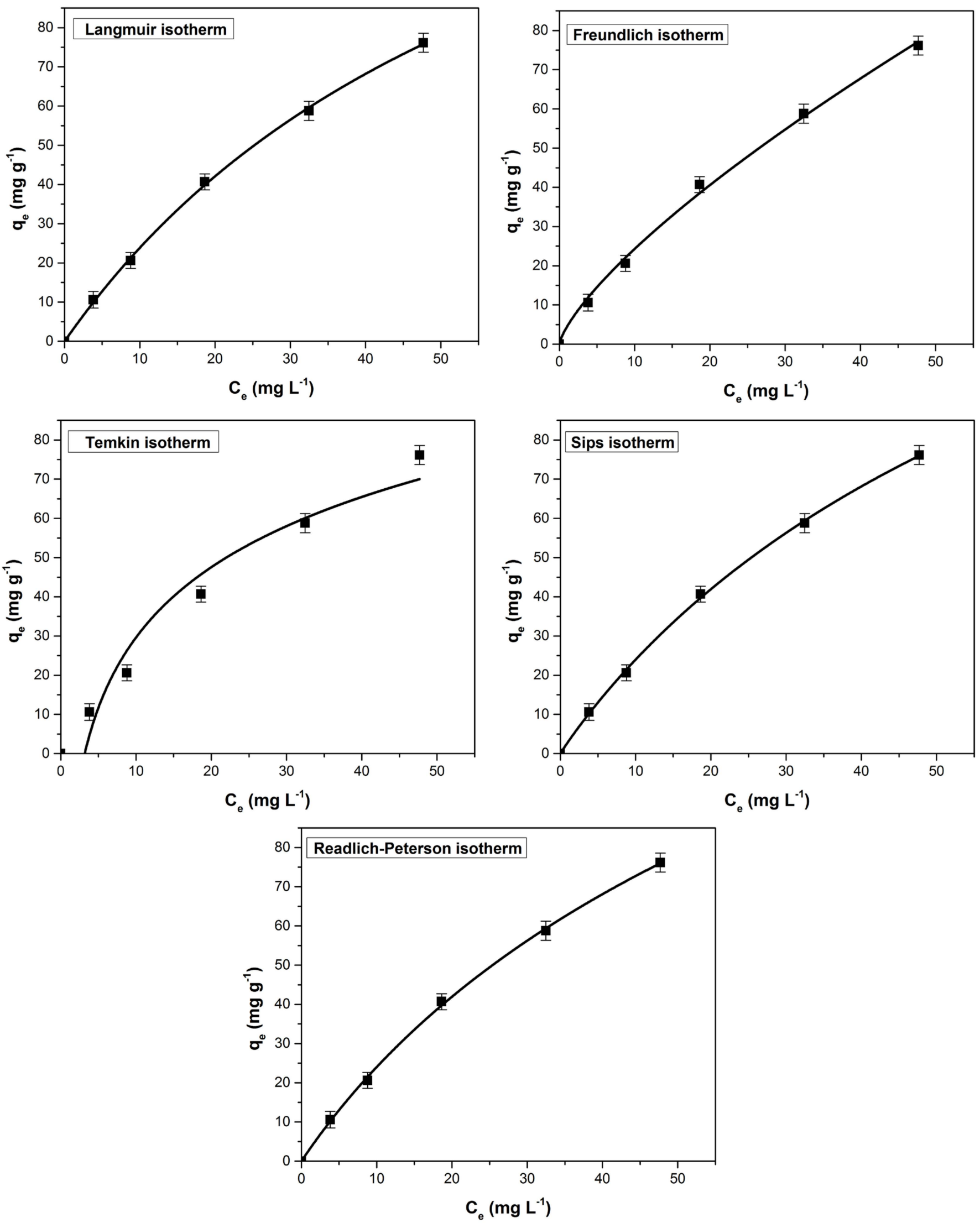

Figure 11. The tested adsorption isotherms (non-linear forms) for the methylene blue adsorption on bioadsorbent obtained from bilberry (Vaccinium myrtillus L.) leaves. 
Table 4. The adsorption isotherms models constants and the corresponding error functions.

\begin{tabular}{|c|c|c|}
\hline Isotherm Model & Parameters & Value \\
\hline \multirow{7}{*}{ Langmuir non-linear } & $K_{L}\left(\mathrm{~L} \mathrm{mg}^{-1}\right)$ & $0.015 \pm 0.001$ \\
\hline & $q_{\max }\left(\mathrm{mg} \mathrm{g}^{-1}\right)$ & $180.1 \pm 5.17$ \\
\hline & $R^{2}$ & 0.9994 \\
\hline & $\chi^{2}$ & 0.0993 \\
\hline & SSE & 2.47 \\
\hline & ARE (\%) & 2.80 \\
\hline & $K_{f}\left(\mathrm{mg} \mathrm{g}^{-1}\right)$ & $4.41 \pm 0.81$ \\
\hline \multirow{5}{*}{ Freundlich non-linear } & $1 / n$ & $0.74 \pm 0.04$ \\
\hline & $R^{2}$ & 0.9977 \\
\hline & $\chi^{2}$ & 0.3887 \\
\hline & SSE & 10.13 \\
\hline & ARE (\%) & 5.18 \\
\hline \multirow{7}{*}{ Temkin non-linear } & $K_{T}\left(\mathrm{~L} \mathrm{mg}^{-1}\right)$ & $0.314 \pm 0.057$ \\
\hline & $b\left(\mathrm{~kJ} \mathrm{~g}^{-1}\right)$ & $94.94 \pm 4.69$ \\
\hline & $R^{2}$ & 0.9695 \\
\hline & $\chi^{2}$ & 9.6559 \\
\hline & SSE & 131.51 \\
\hline & ARE $(\%)$ & 33.60 \\
\hline & $Q_{\text {sat }}\left(\mathrm{mg} \mathrm{g}^{-1}\right)$ & $200.4 \pm 5.74$ \\
\hline \multirow{6}{*}{ Sips non-linear } & $K_{S}\left(\mathrm{~L} \mathrm{mg}^{-1}\right)$ & $0.014 \pm 0.002$ \\
\hline & $n$ & 0.9625 \\
\hline & $R^{2}$ & 0.9994 \\
\hline & $x^{2}$ & 0.0784 \\
\hline & SSE & 2.25 \\
\hline & ARE (\%) & 2.27 \\
\hline \multirow{7}{*}{ Redlich-Peterson non-linear } & $K_{R P}\left(\mathrm{~L} \mathrm{~g}^{-1}\right)$ & $2.90 \pm 0.65$ \\
\hline & $a_{R P}\left(\mathrm{~L} \mathrm{mg}^{-1}\right)$ & $0.028 \pm 0.003$ \\
\hline & $\beta_{\mathrm{RP}}$ & $0.87 \pm 0.09$ \\
\hline & $R^{2}$ & 0.9994 \\
\hline & $\chi^{2}$ & 0.0827 \\
\hline & SSE & 2.28 \\
\hline & ARE (\%) & 2.37 \\
\hline
\end{tabular}

Table 5 compares the maximum adsorption capacities obtained for similar bio-materials used for the methylene blue adsorption. The comparison reveals that our material have a better adsorption capacity than many other studied bioadsorbents.

Table 5. The maximum adsorption capacities for a several similar biomaterials used for the methylene blue adsorption.

\begin{tabular}{ccc}
\hline Adsorbent & $\begin{array}{c}\text { Maximum Adsorption } \\
\text { Capacity }\left(\mathbf{m g ~ g}^{-\mathbf{1}}\right)\end{array}$ & Reference \\
\hline Arthrospira platensis biomass & 312.5 & {$[25]$} \\
guava leaf powder & 295.04 & {$[83]$} \\
lotus leaf & 221.7 & {$[62]$} \\
Vaccinium myrtillus L. leaves powder & $\mathbf{2 0 0 . 4}$ & This study \\
Syringa vulgaris leaves powder & 188.2 & {$[84]$} \\
Humulus japonicas leaves & 145.56 & {$[24]$} \\
Platanus orientalis leaf powder & 114.9 & {$[28]$} \\
tea waste & 113.14 & {$[63]$} \\
Cocos nucifera leaf & 112.35 & {$[85]$} \\
banana leaves & 109.9 & {$[86]$} \\
Typha angustifolia leaves & 106.75 & {$[23]$} \\
Elaeis guineensis leaves & 103.0 & {$[22]$} \\
phoenix tree's leaves & 80.9 & {$[30]$} \\
\hline
\end{tabular}


Table 5. Cont.

\begin{tabular}{|c|c|c|}
\hline Adsorbent & $\begin{array}{c}\text { Maximum Adsorption } \\
\text { Capacity }\left(\mathrm{mg} \mathrm{g}^{-1}\right)\end{array}$ & Reference \\
\hline Daucus carota leaves powder & 66.5 & [38] \\
\hline Salix babylonica leaves & 60.9 & [27] \\
\hline Phragmites australis biomass & 58.82 & [71] \\
\hline potato leaves powder & 52.60 & [87] \\
\hline Carica papaya wood & 32.25 & [73] \\
\hline Ginkgo biloba leaves & 48.07 & [74] \\
\hline Archidendron jiringa seed shells & 44.64 & [70] \\
\hline Neem leaf powder & 19.6 & [88] \\
\hline Citrullus colocynthis seeds & 18.83 & [1] \\
\hline Citrullus colocynthis peels & 4.36 & [1] \\
\hline
\end{tabular}

\subsection{Influence of Temperature on Dye Adsorption. Process Thermodynamics}

Figure 12 shows the influence of increasing temperature on the adsorption capacity and dye removal efficiency. Both parameters increase with the increase in temperature from 278 to $311 \mathrm{~K}$ denoting that the process is endothermic in nature [1,84]. The results are in agreement with results obtained in other previous studies that use bioadsorbents for methylene blue adsorption $[27,28,62]$ and can be explained by reducing the solution's viscosity as the temperature increases. Thus, increasing dye molecules' mobility leads to an increase in the diffusion rate in the pores of the adsorbent material [47,84].

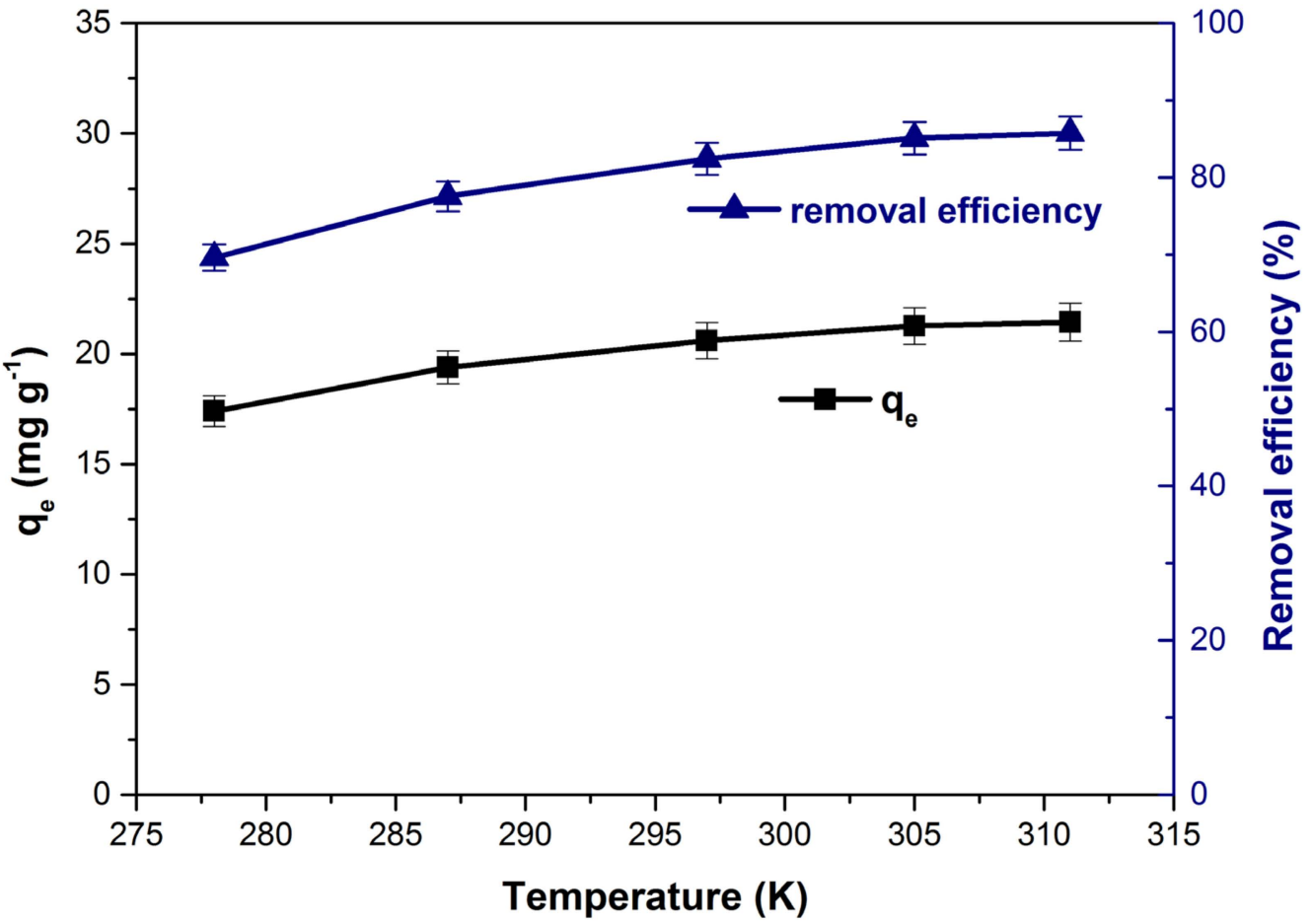

Figure 12. Influence of temperature on the adsorption capacity and dye removal efficiency.

Analyzing the thermodynamic parameters (Table 6) calculated based on the data obtained from Figure 13, it can be stated that the adsorption process is spontaneous, favorable and endothermic ( $\Delta \mathrm{G}^{0}$ is negative and $\Delta \mathrm{H}^{0}$ is positive). The positive value of $\Delta S^{0}$ indicate an increased degree of disorder at the adsorbent-liquid interface and shows the adsorbent's affinity for methylene blue. Similar observations were mentioned in other studies which aimed the methylene blue removal on similar bioadsorbents $[16,22,62,88]$. 
Table 6. The thermodynamic parameters for the methylene blue adsorption on bioadsorbent obtained from bilberry (Vaccinium myrtillus L.) leaves.

\begin{tabular}{|c|c|c|c|c|c|c|}
\hline \multicolumn{5}{|c|}{$\Delta \mathrm{G}^{0}\left(\mathrm{~kJ} \mathrm{~mol}^{-1}\right)$} & \multirow{2}{*}{$\Delta \mathrm{H}^{0}\left(\mathrm{~kJ} \mathrm{~mol}{ }^{-1}\right)$} & \multirow{2}{*}{$\Delta S^{0}\left(\mathrm{~J} \mathrm{~mol}^{-1} \mathrm{~K}^{-1}\right)$} \\
\hline $278 \mathrm{~K}$ & $287 \mathrm{~K}$ & $297 \mathrm{~K}$ & $303 \mathrm{~K}$ & $311 \mathrm{~K}$ & & \\
\hline-18.91 & -20.19 & -21.56 & -22.23 & -23.1 & 2.02 & 15.49 \\
\hline
\end{tabular}

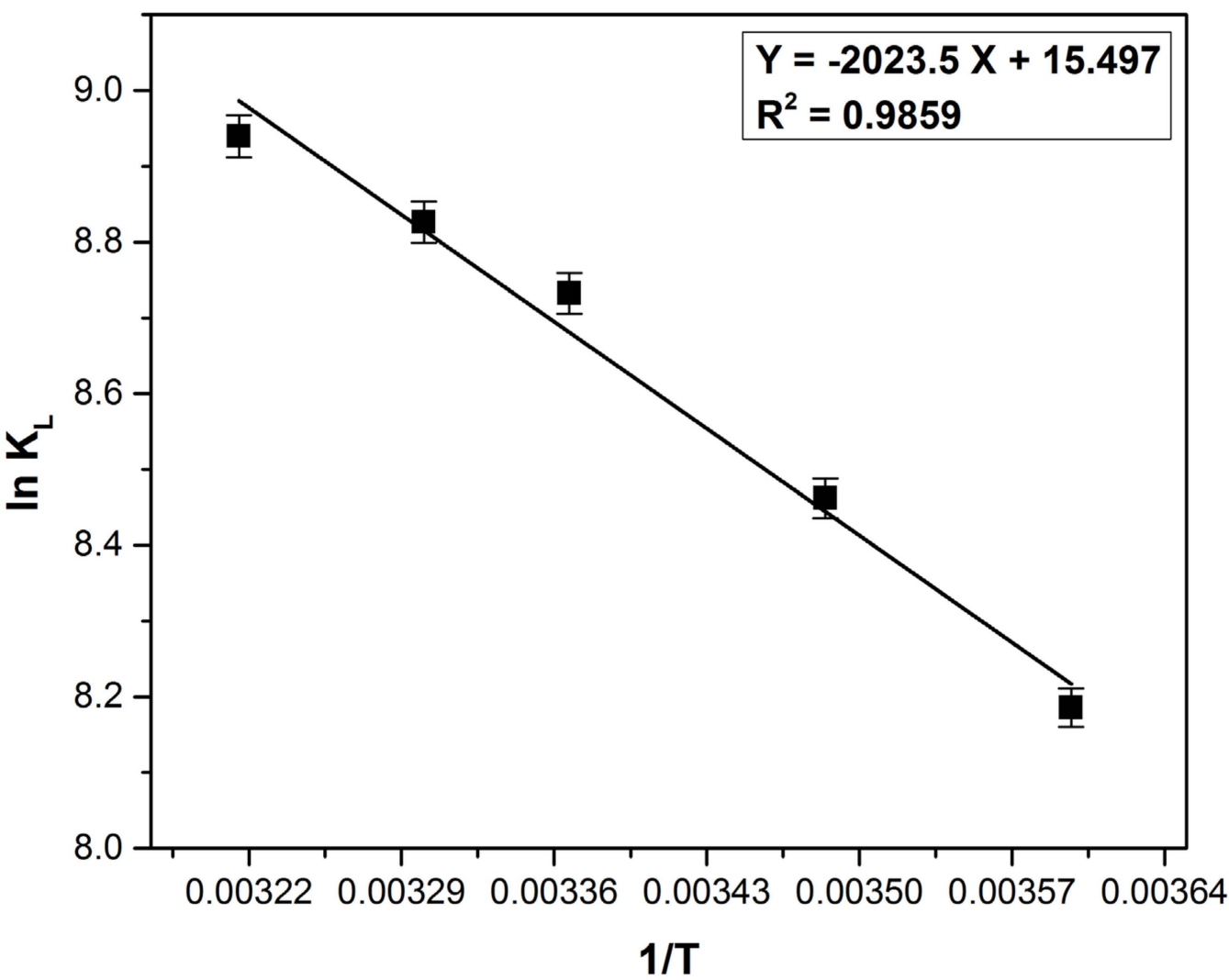

Figure 13. Plot of $\ln \mathrm{K}_{\mathrm{L}}$ vs. 1/T for the methylene blue adsorption on bioadsorbent obtained from bilberry (Vaccinium myrtillus L.) leaves.

The value of $\Delta \mathrm{H}^{0}$ lower than $20\left(\mathrm{~kJ} \mathrm{~mol}^{-1}\right)$ reveals the physical adsorption presence [89] with van der Waals interaction implied in the process mechanism [84,90]. The physisorption is involved in the process when $\Delta \mathrm{G}^{0}$ ranges from -20 to $0\left(\mathrm{~kJ} \mathrm{~mol}^{-1}\right)$ and the physisorption together with chemisorption is involved when $\Delta \mathrm{G}^{0}$ ranges from -20 to $-80\left(\mathrm{~kJ} \mathrm{~mol}^{-1}\right)[29,91,92]$. The $\Delta \mathrm{G}^{0}$ value (Table 5) indicates the involvement of physisorption, but a small chemical effect may enhance the process.

\subsection{Taguchi Optimization}

The L25 orthogonal array used in the experiments and results obtained after each run are presented in Table 7 . The $\mathrm{S} / \mathrm{N}$ ratio for the controllable factors along with delta values (the difference between the highest and lowest average response values for each factor) and factors' significance ranks are summarized in Table 8. The optimum dye removal conditions removal are marked with an asterisk. The factor with the highest influence on the dye removal process is $\mathrm{pH}$, followed by contact time, temperature, adsorbent dose, ionic strength and initial dye concentration. The same order of controllable factor influence was confirmed by ANOVA analysis with which the percentages contribution were also determined (Table 8). 
Table 7. The L25 orthogonal array used in the experiments and results obtained after each run.

\begin{tabular}{|c|c|c|c|c|c|c|c|}
\hline $\mathrm{pH}$ & $\begin{array}{c}\text { Adsorbent } \\
\text { Dose }\end{array}$ & $\begin{array}{c}\text { Ionic } \\
\text { Strenght }\end{array}$ & Time & $\begin{array}{l}\text { Initial Dye } \\
\text { Concentration }\end{array}$ & Temperature & $\begin{array}{c}\text { Dye Removal } \\
\text { Efficiency }\end{array}$ & S/N Ratio \\
\hline 2 & 1 & 0 & 5 & 25 & 278 & 32.95 & 30.35 \\
\hline 2 & 2 & 0.05 & 15 & 50 & 287 & 47.23 & 33.48 \\
\hline 2 & 3 & 0.1 & 30 & 100 & 297 & 51.78 & 34.28 \\
\hline 2 & 4 & 1.15 & 40 & 150 & 305 & 51.18 & 34.18 \\
\hline 2 & 5 & 2 & 50 & 200 & 311 & 50.01 & 33.98 \\
\hline 3 & 2 & 2 & 5 & 100 & 305 & 50.39 & 34.04 \\
\hline 3 & 3 & 0 & 15 & 150 & 311 & 69.6 & 36.85 \\
\hline 3 & 4 & 0.05 & 30 & 200 & 278 & 57.01 & 35.11 \\
\hline 3 & 5 & 0.1 & 40 & 25 & 287 & 69.41 & 36.82 \\
\hline 3 & 1 & 1.15 & 50 & 50 & 297 & 60 & 35.56 \\
\hline 6 & 3 & 1.15 & 5 & 200 & 287 & 51.16 & 34.17 \\
\hline 6 & 4 & 2 & 15 & 25 & 297 & 74.46 & 37.43 \\
\hline 6 & 5 & 0 & 30 & 50 & 305 & 87.92 & 38.88 \\
\hline 6 & 1 & 0.05 & 40 & 100 & 311 & 75.21 & 37.52 \\
\hline 6 & 2 & 0.1 & 50 & 150 & 278 & 62.44 & 35.90 \\
\hline 8 & 4 & 0.1 & 5 & 50 & 311 & 65.24 & 36.29 \\
\hline 8 & 5 & 1.15 & 15 & 100 & 278 & 62.26 & 35.88 \\
\hline 8 & 1 & 2 & 30 & 150 & 287 & 59.91 & 35.55 \\
\hline 8 & 2 & 0 & 40 & 200 & 297 & 77.37 & 37.77 \\
\hline 8 & 3 & 0.05 & 50 & 25 & 305 & 90.44 & 39.12 \\
\hline 10 & 5 & 0.05 & 5 & 150 & 297 & 62.43 & 35.90 \\
\hline 10 & 1 & 0.1 & 15 & 200 & 305 & 63.95 & 36.11 \\
\hline 10 & 2 & 1.15 & 30 & 25 & 311 & 79.82 & 38.04 \\
\hline 10 & 3 & 2 & 40 & 50 & 278 & 65.9 & 36.37 \\
\hline 10 & 4 & 0 & 50 & 100 & 287 & 82.17 & 38.29 \\
\hline
\end{tabular}

Table 8. Response table for signal-to-noise $\mathrm{S} / \mathrm{N}$ ratios (larger is better).

\begin{tabular}{|c|c|c|c|c|c|c|}
\hline Level & $\mathrm{pH}$ & $\begin{array}{l}\text { Adsorbent } \\
\text { Dose }\end{array}$ & $\begin{array}{c}\text { Ionic } \\
\text { Strenght }\end{array}$ & Time & $\begin{array}{l}\text { Initial Dye } \\
\text { Concentration }\end{array}$ & Temperature \\
\hline 1 & 33.26 & 35.02 & $36.43 *$ & 34.16 & $36.36^{*}$ & 34.73 \\
\hline 2 & 35.68 & 35.85 & 36.23 & 35.96 & 36.12 & 35.67 \\
\hline 3 & 36.79 & 36.16 & 35.89 & 36.38 & 36.01 & 36.19 \\
\hline 4 & 36.92 & 36.26 & 35.57 & 36.54 & 35.68 & 36.47 \\
\hline 5 & $36.95 *$ & $36.30 *$ & 35.48 & $36.57 *$ & 35.43 & $36.54 *$ \\
\hline Delta & 3.69 & 1.27 & 0.95 & 2.42 & 0.93 & 1.81 \\
\hline Rank & 1 & 4 & 5 & 2 & 6 & 3 \\
\hline Contribution $(\%)$ & 53.34 & 6.05 & 3.63 & 22.11 & 2.86 & 12.00 \\
\hline
\end{tabular}

\subsection{Desorption Study}

Figure 14 shows the desorption efficiency values for the three regenerating agents used. The very low desorption percent in distilled water shows that the adsorption is not dominated by weak bonds [93]. The desorption results obtained using $\mathrm{HCl}$ and $\mathrm{NaOH}$ indicate that ion exchange may be involved in adsorption but it doesn't have a very significant role and other strong forces intervene in process [94-96]. These observations are consistent with thermodynamic studies that have shown the involvement of physical adsorption enhanced by a chemical effect in the dye retention process.

$\mathrm{HCl}$ and $\mathrm{NaOH}$ had approximately the same desorption percentage but its value (below 25\%) makes the desorption process not cost-effective, both technically and economically. However, the adsorbent material is easily found in large quantities in nature, so the fact that it cannot be regenerated is not a disadvantage. The exhausted adsorbent can be directly incinerated or used as foaming agent to obtain ceramic or glass foams. 


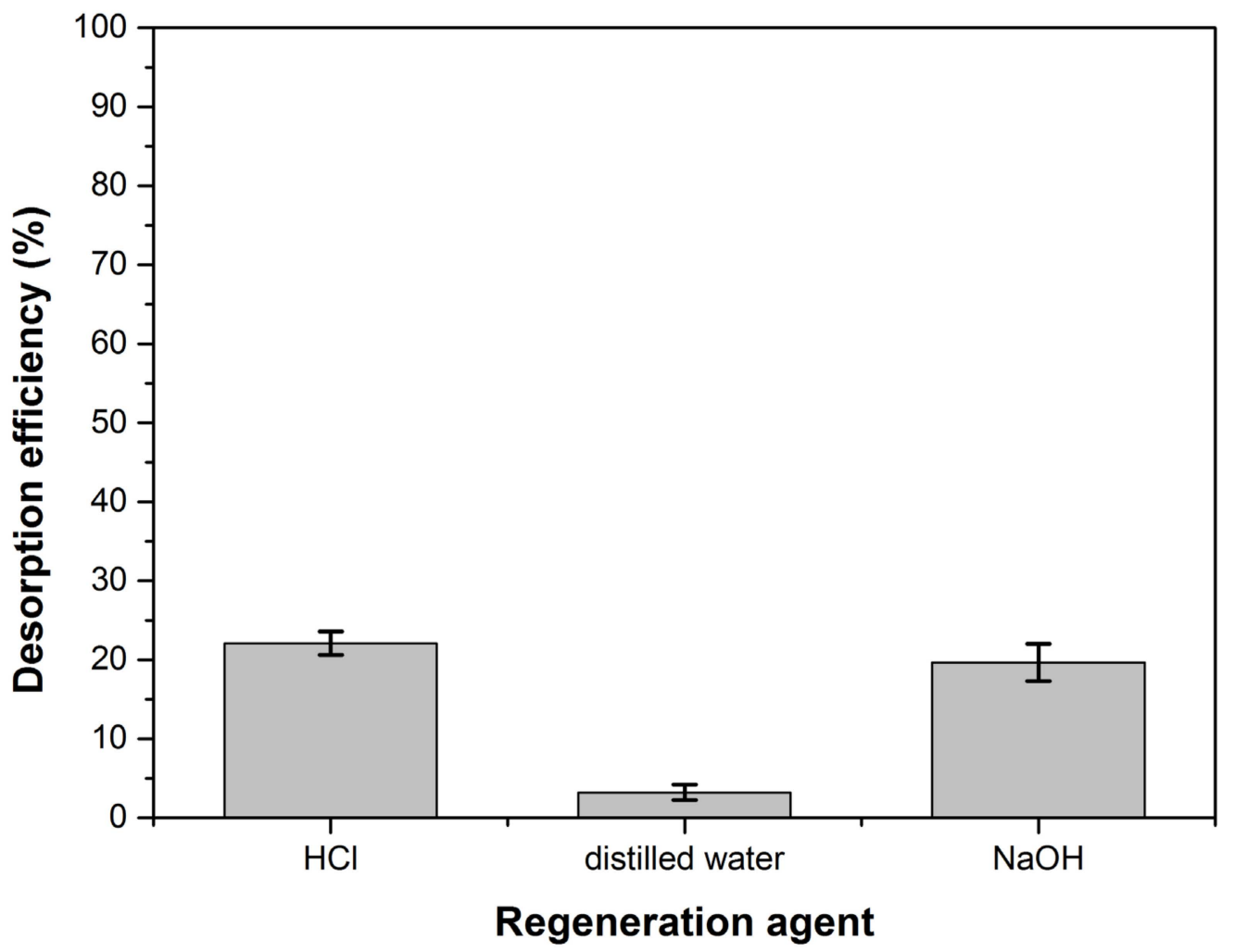

Figure 14. The desorption efficiency for the regeneration agents.

\section{Conclusions}

The lignocellulosic material, bilberry (Vaccinium myrtillus L.) leaves powder, was used with high efficiency to remove the methylene blue dye from aqueous solutions. The $\mathrm{pH}$, bioadsorbent dose, ionic strength, contact time, initial dye concentration, temperature influence the adsorption capacity and the dye removal efficiency. The adsorption is best described by Sips isotherm and general order kinetic model. The process is spontaneous, favorable and endothermic, involving a physisorption mechanism that can be enhanced by a small chemical effect. The factors with the higher percentages contribution on the dye removal efficiency were $\mathrm{pH}(53.34 \%)$ follow by contact time $(22.11 \%)$ and temperature $(12.00 \%)$. The material has a better absorption capacity compared to other similar adsorbents and has the advantage that it is easily available in nature, in large quantities, at a low cost.

Author Contributions: Conceptualization, G.M., C.V. and S.P.; methodology, G.M.; software, G.M. and C.V.; validation, G.M. and M.D.; formal analysis, G.M., C.V. and S.P.; investigation, G.M., S.P., M.D. and S.B.; resources, G.M.; data curation, G.M.; writing-original draft preparation, G.M., C.V., S.P. and S.B.; writing-review and editing, G.M., C.V. and S.P.; visualization, G.M.; supervision, G.M. All authors have read and agreed to the published version of the manuscript.

Funding: This research received no external funding.

Institutional Review Board Statement: Not applicable.

Informed Consent Statement: Not applicable.

Data Availability Statement: All the experimental data obtained are presented, in the form of table and/or figure, in the article.

Conflicts of Interest: The authors declare no conflict of interest. 


\section{References}

1. Alghamdi, W.M.; El Mannoubi, I. Investigation of seeds and peels of Citrullus colocynthis as efficient natural adsorbent for Methylene blue dye. Processes 2021, 9, 1279. [CrossRef]

2. Alvarez-Torrellas, S.; Boutahala, M.; Boukhalfa, N.; Munoz, M. Effective adsorption of methylene blue dye onto magnetic nanocomposites. Modeling and Reuse Studies. Appl. Sci. 2019, 9, 4563. [CrossRef]

3. Chu, T.P.M.; Nguyen, N.T.; Vu, T.L.; Dao, T.H.; Dinh, L.C.; Nguyen, H.L.; Hoang, T.H.; Le, T.S.; Pham, T.D. Synthesis, characterization, and modification of alumina nanoparticles for cationic dye removal. Materials 2019, 12, 450. [CrossRef] [PubMed]

4. De Luca, P.; Nagy, J.B. Treatment of water contaminated with reactive black-5 dye by carbon nanotubes. Materials 2020, 13, 5508. [CrossRef] [PubMed]

5. Maleš, L.; Fakin, D.; Bračič, M.; Gorgieva, S. Efficiency of differently processed membranes based on cellulose as cationic dye adsorbents. Nanomaterials 2020, 10, 642. [CrossRef]

6. Salzano de Luna, M.; Greco, F.; Pastore, R.; Mensitieri, G.; Filippone, G.; Aprea, P.; Mallamace, D.; Mallamace, F.; Chen, S.-H. Tailoring chitosan/LTA zeolite hybrid aerogels for anionic and cationic dye adsorption. Int. J. Mol. Sci. 2021, 22, 5535. [CrossRef] [PubMed]

7. Sui, W.; Pang, T.; Wang, G.; Liu, C.; Parvez, A.M.; Si, C.; Li, C. Stepwise ethanol-water fractionation of enzymatic hydrolysis lignin to improve its performance as a cationic dye adsorbent. Molecules 2020, 25, 2603. [CrossRef]

8. Abualnaja, K.M.; Alprol, A.E.; Abu-Saied, M.A.; Ashour, M.; Mansour, A.T. Removing of anionic dye from aqueous solutions by adsorption using of multiwalled carbon nanotubes and poly (Acrylonitrile-styrene) impregnated with activated carbon. Sustainability 2021, 13, 7077. [CrossRef]

9. Chahinez, H.-O.; Abdelkader, O.; Leila, Y.; Tran, H.N. One-stage preparation of palm petiole-derived biochar: Characterization and application for adsorption of crystal violet dye in water. Environ. Technol. Innov. 2020, 19, 100872. [CrossRef]

10. Franco, D.S.P.; Fagundes, J.L.S.; Georgin, J.; Salaua, N.P.G.; Dotto, G.L. A mass transfer study considering intraparticle diffusion and axial dispersion for fixed-bed adsorption of crystal violet on pecan pericarp (Carya illinoensis). Chem. Eng. J. 2020, 397, 125423 [CrossRef]

11. Valério Filho, A.; Xavaré Kulman, R.; Vaz Tholozan, L.; Felkl de Almeida, A.R.; Silveira da Rosa, G. Preparation and characterization of activated carbon obtained from water treatment plant sludge for removal of cationic dye from wastewater. Processes $\mathbf{2 0 2 0}$ 8, 1549. [CrossRef]

12. Foroutan, R.; Mohammadi, R.; MousaKhanloo, F.; Sahebi, S.; Ramavandi, B.; Kumar, P.S.; Vardhan, K.H. Performance of montmorillonite/graphene oxide/ $\mathrm{CoFe}_{2} \mathrm{O}_{4}$ as a magnetic and recyclable nanocomposite for cleaning methyl violet dye-laden wastewater. Adv. Powder Technol. 2020, 31, 3993-4004. [CrossRef]

13. Foroutan, R.; Peighambardoust, S.J.; Peighambardoust, S.H.; Pateiro, M.; Lorenzo, J.M. Adsorption of crystal violet dye using activated carbon of lemon wood and activated carbon $/ \mathrm{Fe}_{3} \mathrm{O}_{4}$ magnetic nanocomposite from aqueous solutions: A kinetic, equilibrium and thermodynamic study. Molecules 2021, 26, 2241. [CrossRef]

14. Choudhary, N.; Yadav, V.K.; Yadav, K.K.; Almohana, A.I.; Almojil, S.F.; Gnanamoorthy, G.; Kim, D.-H.; Islam, S.; Kumar, P.; Jeon, B.-H. Application of green synthesized MMT/Ag nanocomposite for removal of methylene blue from aqueous solution. Water 2021, 13, 3206. [CrossRef]

15. Giraldo, S.; Robles, I.; Godínez, L.A.; Acelas, N.; Flórez, E. Experimental and theoretical insights on methylene blue removal from wastewater using an adsorbent obtained from the residues of the orange industry. Molecules 2021, 26, 4555. [CrossRef] [PubMed]

16. Shakoor, S.; Nasar, A. Removal of methylene blue dye from artificially contaminated water using citrus limetta peel waste as a very low cost adsorbent. J. Taiwan. Inst. Chem. Eng. 2016, 66, 154-163. [CrossRef]

17. Sharma, K.; Sharma, S.; Sharma, V.; Mishra, P.K.; Ekielski, A.; Sharma, V.; Kumar, V. Methylene blue dye adsorption from wastewater using hydroxyapatite/gold nanocomposite: Kinetic and thermodynamics studies. Nanomaterials 2021, 11, 1403. [CrossRef] [PubMed]

18. Filho, A.C.D.; Mazzocato, A.C.; Dotto, G.L.; Thue, P.S.; Pavan, F.A. Eragrostis plana Nees as a novel eco-friendly adsorbent for removal of crystal violet from aqueous solutions. Environ. Sci. Pollut. Res. 2017, 24, 19909-19919. [CrossRef] [PubMed]

19. Georgin, J.; Franco, D.S.P.; Netto, M.S.; Allasia, D.; Oliveira, M.L.S.; Dotto, G.L. Evaluation of Ocotea puberula bark powder (OPBP) as an effective adsorbent to uptake crystal violet from colored effluents: Alternative kinetic approaches. Environ. Sci. Pollut. Res. 2020, 27, 25727-25739. [CrossRef] [PubMed]

20. Mokhtar, N.; Aziz, E.A.; Aris, A.; Ishak, W.F.W.; Ali, N.S.M. Biosorption of azo-dye using marine macro-alga of Euchema Spinosum. J. Environ. Chem. Eng. 2017, 5, 5721-5731. [CrossRef]

21. Reddy, P.M.K.; Verma, P.; Subrahmanyam, C. Bio-waste derived adsorbent material for methylene blue adsorption. J. Taiwan Inst. Chem. Eng. 2016, 58, 500-508. [CrossRef]

22. Setiabudi, H.D.; Jusoh, R.; Suhaimi, S.F.R.M.; Masrur, S.F. Adsorption of methylene blue onto oil palm (Elaeis guineensis) leaves: Process optimization, isotherm, kinetics and thermodynamic studies. J. Taiwan Inst. Chem. Eng. 2016, 63, 363-370. [CrossRef]

23. Boumaza, S.; Yenounne, A.; Hachi, W.; Kaouah, F.; Bouhamidi, Y.; Trari, M. Application of Typha angustifolia (L.) Dead leaves waste as biomaterial for the removal of cationic dye from aqueous solution. Int. J. Environ. Res. 2018, 12, 561-573. [CrossRef]

24. Huang, Z.G.; Wang, T.; Yi, H.Y.; Li, X.B. Study on the adsorption of methylene blue from dye wastewater by Humulus japonicus leaves. In E3S Web of Conferences; EDP Sciences: Ulis, France, 2021; Volume 236, p. 03028. [CrossRef] 
25. Mitrogiannis, D.; Markou, G.; Çelekli, A.; Bozkurt, H. Biosorption of methylene blue onto Arthrospira platensis biomass: Kinetic, equilibrium and thermodynamic studies. J. Environ. Chem. Eng. 2015, 3, 670-680. [CrossRef]

26. Bulgariu, L.; Escudero, L.B.; Bello, O.S.; Iqbal, M.; Nisar, J.; Adegoke, K.A.; Alakhras, F.; Kornaros, M.; Anastopoulos, I. The utilization of leaf-based adsorbents for dyes removal: A review. J. Mol. Liq. 2019, 276, 728-747. [CrossRef]

27. Khodabandehloo, A.; Rahbar-Kelishami, A.; Shayesteh, H. Methylene blue removal using Salix babylonica (Weeping willow) leaves powder as a low-cost biosorbent in batch mode: Kinetic, equilibrium, and thermodynamic studies. J. Mol. Liq. 2017, 244, 540-548. [CrossRef]

28. Peydayesh, M.; Rahbar-Kelishami, A. Adsorption of methylene blue onto Platanus orientalis leaf powder: Kinetic, equilibrium and thermodynamic studies. J. Ind. Eng. Chem. 2015, 21, 1014-1019. [CrossRef]

29. Weng, C.H.; Lin, Y.T.; Tzeng, T.W. Removal of methylene blue from aqueous solution by adsorption onto pineapple leaf powder. J. Hazard. Mater. 2009, 170, 417-424. [CrossRef]

30. Han, R.; Zou, W.; Yu, W.; Cheng, S.; Wang, Y.; Shi, J. Biosorption of methylene blue from aqueous solution by fallen phoenix tree's leaves. J. Hazard. Mater. 2007, 141, 156-162. [CrossRef]

31. Nestby, R.; Percival, D.; Martinussen, I.; Opstad, N.; Rohloff, J. The european blueberry (Vaccinium myrtillus L.) and the potential for cultivation. A review. Eur. J. Plant Sci. Biotechnol. 2011, 5, 5-16.

32. Mažeikienè, I.; Frercks, B.; Burokienè, D.; Mačionienė, I.; Šalaševičienè, A. Endophytic community composition and geneticenzymatic features of cultivable bacteria in Vaccinium myrtillus L. in forests of the Baltic-Nordic region. Forests 2021, $12,1647$. [CrossRef]

33. Bujor, O.; Le, B.C.; Volf, I.; Popa, V.I.; Dufour, C. Seasonal variations of the phenolic constituents in bilberry (Vaccinium myrtillus L.) leaves, stems and fruits, and their antioxidant activity. Food Chem. 2016, 213, 58-68. [CrossRef] [PubMed]

34. Mikulic-Petkovsek, M.; Schmitzer, V.; Slatnar, A.; Stampar, F.; Veberic, R. Composition of sugars, organic acids, and total phenolics in 25 wild or cultivated berry species. J. Food Sci. 2012, 77, C1064-C1070. [CrossRef] [PubMed]

35. Pires, T.C.S.P.; Caleja, C.; Santos-Buelga, C.; Barros, L.; Ferreira, I.C. Vaccinium myrtillus L. Fruits as a Novel source of phenolic compounds with health benefits and industrial applications-A review. Curr. Pharm. Des. 2020, 26, 1917-1928. [CrossRef] [PubMed]

36. Zorenc, Z.; Veberic, R.; Mikulic-Petkovsek, M. Are processed bilberry products a good source of phenolics? J. Food Sci. 2018, 83, 1856-1861. [CrossRef] [PubMed]

37. Ziemlewska, A.; Zagórska-Dziok, M.; Nizioł-Łukaszewska, Z. Assessment of cytotoxicity and antioxidant properties of berry leaves as by-products with potential application in cosmetic and pharmaceutical products. Sci. Rep. 2021, 11, 3240. [CrossRef] [PubMed]

38. Kushwaha, A.K.; Gupta, N.; Chattopadhyaya, M.C. Removal of cationic methylene blue and malachite green dyes from aqueous solution by waste materials of Daucus carota. J. Saudi. Chem. Soc. 2014, 18, 200-207. [CrossRef]

39. Zaidi, N.A.H.M.; Lim, L.B.L.; Usman, A. Artocarpus odoratissimus leaf-based cellulose as adsorbent for removal of methyl violet and crystal violet dyes from aqueous solution. Cellulose 2018, 25, 3037-3049. [CrossRef]

40. Dotto, G.L.; Salau, N.P.G.; Piccin, J.S.; Cadaval, T.R.S.; de Pinto, L.A.A. Adsorption kinetics in liquid phase: Modeling for discontinuous and continuous systems. In Adsorption Processes for Water Treatment and Purification; Bonilla-Petriciolet, A., Mendoza-Castillo, D., Reynel-Avila, H., Eds.; Springer: Cham, Switzerland, 2017; pp. 53-76.

41. Esquerdo, V.M.; Quintana, T.M.; Dotto, G.L.; Pinto, L.A.A. Kinetics and mass transfer aspects about the adsorption of tartrazine by a porous chitosan sponge. Reac. Kinet. Mech. Cat. 2015, 116, 105-117. [CrossRef]

42. Netto, M.S.; Georgin, J.; Franco, D.S.P.; Mallmann, E.S.; Foletto, E.L.; Godinho, M.; Pinto, D.; Dotto, G.L. Effective adsorptive removal of atrazine herbicide in river waters by a novel hydrochar derived from Prunus serrulata bark. Environ. Sci. Pollut. Res. 2021, 29, 3672-3685. [CrossRef] [PubMed]

43. Piccin, J.S.; Cadaval, T.R.S.; de Pinto, L.A.A.; Dotto, G.L. Adsorption isotherms in liquid phase: Experimental, modeling, and interpretations. In Adsorption Processes for Water Treatment and Purification; Bonilla-Petriciolet, A., Mendoza-Castillo, D., Reynel-Avila, H., Eds.; Springer: Cham, Switzerland, 2017; pp. 19-51.

44. Fernández-López, J.A.; Angosto, J.M.; Roca, M.J.; Miñarro, M.D. Taguchi design-based enhancement of heavy metals bioremoval by agroindustrial waste biomass from artichoke. Sci. Total. Environ. 2018, 653, 55-63. [CrossRef]

45. Zolgharnein, J.; Rastgordani, M. Optimization of simultaneous removal of binary mixture of indigo carmine and methyl orange dyes by cobalt hydroxide nano-particles through Taguchi method. J. Mol. Liq. 2018, 262, 405-414. [CrossRef]

46. Kokot, S.; Czarnik-Matusewicz, B.; Ozaki, Y. Two-dimensional correlation spectroscopy and principal component analysis studies of temperature-dependent IR spectra of cotton-cellulose. Biopolymers 2002, 67, 456-469. [CrossRef]

47. Pang, X.; Sellaoui, L.; Franco, D.; Dotto, G.L.; Georgin, J.; Bajahzar, A.; Belmabrouk, H.; Ben Lamine, A.; Bonilla-Petriciolet, A.; $\mathrm{Li}, \mathrm{Z}$. Adsorption of crystal violet on biomasses from pecan nutshell, para chestnut husk, araucaria bark and palm cactus: Experimental study and theoretical modeling via monolayer and double layer statistical physics models. Chem. Eng. J. 2019, 378, 122101. [CrossRef]

48. Asefnejad, A.; Taghi Khorasani, M.; Behnamghader, A.; Farsadzadeh, B.; Bonakdar, S. Manufacturing of biodegradable polyurethane scaffolds based on polycaprolactone using a phase separation method: Physical properties and in vitro assay. Int. J. Nanomed. 2011, 6, 2375-2384. [CrossRef] [PubMed] 
49. Djelad, A.; Mokhtar, A.; Khelifa, A.; Bengueddach, A.; Sassia, M. Alginate-whey an effective and green adsorbent for crystal violet removal: Kinetic, thermodynamic and mechanism studies. Int. J. Biol. Macromol. 2019, 139, 944-954. [CrossRef] [PubMed]

50. Senthamaraikannan, P.; Sanjay, M.R.; Bhat, K.S.; Padmaraj, N.H.; Jawaid, M. Characterization of natural cellulosic fiber frombark of Albizia amara. J. Nat. Fibers 2018, 20, 1124-1131.

51. Shaharuddin, S.; Razak, S.I.A.; Muhamad, I.I. Sugarcane bagasse as the potential agro-waste resource for the immobilization of Lactobacillus rhamnosus NRRL 442. Adv. Mat. Res. 2014, 1043, 214-218. [CrossRef]

52. Barth, A. Infrared spectroscopy of proteins. Biochim. Biophys. Acta Bioenerg. 2007, 1767, 1073-1101. [CrossRef]

53. Grassi, P.; Reis, C.; Drumm, F.C.; Georgin, J.; Tonato, D.; Escudero, L.B.; Kuhn, R.; Jahn, S.L.; Dotto, G.L. Biosorption of crystal violet dye using inactive biomass of the fungus Diaporthe schini. Water Sci. Technol. 2019, 79, 709-717. [CrossRef] [PubMed]

54. Chang, H.T.; Yeh, T.F.; Hsu, F.L.; Kuo-Huang, L.L.; Lee, C.M.; Huang, Y.S.; Chang, S.T. Profiling the chemical composition and growth strain of giant bamboo (Dendrocalamus giganteus Munro). BioResources 2015, 10, 1260-1270. [CrossRef]

55. Sahoo, S.; Seydibeyoglu, M.O.; Mohanty, A.K.; Misra, M. Characterization of industrial lignins for their utilization in future value added applications. Biomass. Bioenergy 2011, 35, 4230-4237. [CrossRef]

56. Popescu, C.M.; Popescu, M.C.; Singurel, G.; Vasile, C.; Argyropoulos, D.S.; Willfor, S. Spectral characterization of eucalyptus wood. Appl. Spectrosc. 2007, 61, 1168-1177. [CrossRef]

57. Thinh, P.X.; Basavaraja, C.; Kim, D.G.; Huh, D.S. Characterization and electrochemical behaviors of honeycomb-patterned poly(N-vinylcarbazole)/polystyrene composite films. Polym. Bull. 2012, 69, 81-94. [CrossRef]

58. Trivedi, M.K.; Tallapragada, R.M.; Branton, A.; Trivedi, D.; Nayak, G.; Mishra, R.K.; Jana, S. Characterization of physical, spectroscopic and thermal properties of biofield treated biphenyl. Am. J. Chem. Eng. 2015, 3, 58-65. [CrossRef]

59. Md Salim, R.; Asik, J.; Sarjadi, M.S. Chemical functional groups of extractives, cellulose and lignin extracted from native Leucaena leucocephala bark. Wood Sci. Technol. 2021, 55, 295-313. [CrossRef]

60. Alshehri, A.A.; Malik, M.A. Biogenic fabrication of $\mathrm{ZnO}$ nanoparticles using Trigonella foenum-graecum (Fenugreek) for proficient photocatalytic degradation of methylene blue under UV irradiation. J. Mater. Sci.: Mater. Electron. 2019, 30, 16156-16173. [CrossRef]

61. Li, B.; Lv, J.Q.; Guo, J.Z.; Fu, S.Y.; Guo, M.; Yang, P. The polyaminocarboxylated modified hydrochar for efficient capturing methylene blue and $\mathrm{Cu}(\mathrm{II})$ from water. Bioresour. Technol. 2019, 275, 360-367. [CrossRef]

62. Han, X.; Wang, W.; Ma, X. Adsorption characteristics of methylene blue onto low cost biomass material lotus leaf. Chem. Eng. J. 2011, 171, 1-8. [CrossRef]

63. Uddin, M.T.; Islam, M.A.; Mahmud, S.; Rukanuzzaman, M. Adsorptive removal of methylene blue by tea waste. J. Hazard. Mater. 2009, 164, 53-60. [CrossRef] [PubMed]

64. Suyamboo, B.K.; Srikrishnaperumal, R. Biosorption of crystal violet onto cyperus rotundus in batch system: Kinetic and equilibrium modeling. Desalin. Water Treat. 2014, 52, 3535-3546. [CrossRef]

65. Quansah, J.O.; Hlaing, T.; Lyonga, F.N.; Kyi, P.P.; Hong, S.-H.; Lee, C.-G.; Park, S.-J. Nascent rice husk as an adsorbent for removing cationic dyes from textile wastewater. Appl. Sci. 2020, 10, 3437. [CrossRef]

66. Silva, F.; Nascimento, L.; Brito, M.; da Silva, K.; Paschoal, W.; Fujiyama, R. Biosorption of methylene blue dye using natural biosorbents made from weeds. Materials 2019, 12, 2486. [CrossRef] [PubMed]

67. Aryee, A.A.; Zhang, R.; Liu, H.; Han, R.; Li, Z.; Qu, L. Application of magnetic peanut husk for methylene blue adsorption in batch mode. Desalin. Water Treat. 2020, 194, 269-279. [CrossRef]

68. Özçelik, G.; Şahin, E.K.; Şahin, S. Effect of ionic strength on methylene blue sorption onto macroporous resins: A comprehensive study. J. Dispers. Sci. Technol. 2020, 1-10. [CrossRef]

69. Al-Ghamdi, Y.O.; Jabli, M.; Soury, R.; Ali Khan, S. A cellulosic fruit derived from nerium oleander biomaterial: Chemical characterization and its valuable use in the biosorption of methylene blue in a batch mode. Polymers 2020, 12, 2539. [CrossRef]

70. Hurairah, S.; Lajis, N.; Halim, A. Methylene blue removal from aqueous solution by adsorption on Archidendron jiringa seed shells. J. Geosci. Environ. Prot. 2020, 8, 128-143. [CrossRef]

71. Kankiliç, G.B.; Metin, A.U.; Tüzün, I. Phragmites australis: An alternative biosorbent for basic dye removal. Ecol. Eng. 2016, 86, 85-94. [CrossRef]

72. Koyuncu, H.; Kul, A.R. Removal of methylene blue dye from aqueous solution by nonliving lichen (Pseudevernia furfuracea (L.) Zopf.), as a novel biosorbent. Appl. Water Sci. 2020, 10, 72. [CrossRef]

73. Rangabhashiyam, S.; Lata, S.; Balasubramanian, P. Biosorption characteristics of methylene blue and malachite green from simulated wastewater onto Carica papaya wood biosorbent. Surf. Interfaces 2018, 10, 197-215.

74. Singh, R.; Singh, T.S.; Odiyo, J.O.; Smith, J.A.; Edokpayi, J.N. Evaluation of methylene blue sorption onto low-cost biosorbents: Equilibrium, kinetics, and thermodynamics. J. Chem. 2020, 2020, 8318049. [CrossRef]

75. Dos Santos, D.C.; Adebayo, M.A.; de Fátima Pinheiro Pereira, S.; Prola, L.D.T.; Cataluña, R.; Lima, E.C.; Saucier, C.; Gally, C.R.; Machado, F.M. New carbon composite adsorbents for the removal of textile dyes from aqueous solutions: Kinetic, equilibrium, and thermodynamic studies. Korean J. Chem. Eng. 2014, 31, 1470-1479. [CrossRef]

76. Ribas, M.C.; Adebayo, M.A.; Prola, L.D.T.; Lima, E.C.; Cataluña, R.; Feris, L.A.; Puchana-Rosero, M.J.; Machado, F.M.; Pavan, F.A.; Calvete, T. Comparison of a homemade cocoa shell activated carbon with commercial activated carbon for the removal of reactive violet 5 dye from aqueous solutions. Chem. Eng. J. 2014, 248, 315-326. [CrossRef] 
77. Saucier, C.; Adebayo, M.A.; Lima, E.C.; Prola, L.D.T.; Thue, P.S.; Umpierres, C.S.; Puchana-Rosero, M.J.; Machado, F.M. Comparison of a homemade bacuri shell activated carbon with carbon nanotubes for food dye removal. Clean 2015, 43, 1389-1400. [CrossRef]

78. Al-Azabi, K.; Al-Marog, S.; Abukrain, A.; Sulyman, M. Equilibrium, isotherm studies of dye adsorption onto orange peel powder. Chem. Res. J. 2018, 3, 45-59.

79. Dawood, S.; Sen, T.K.; Phan, C. Adsorption removal of Methylene Blue (MB) dye from aqueous solution by bio-char prepared from Eucalyptus sheathiana bark: Kinetic, equilibrium, mechanism, thermodynamic and process design. Desalin. Water Treat. 2016, 57, 28964-28980. [CrossRef]

80. Bounaas, M.; Bouguettoucha, A.; Chebli, D.; Reffas, A.; Gatica, J.M.; Amrane, A. Batch adsorption of synthetic dye by Maclura Pomifera, a new eco-friendly waste biomass: Experimental studies and modeling. Int. J. Chem. React. Eng. 2019, 17, 20180063. [CrossRef]

81. Gago, D.; Chagas, R.; Ferreira, L.M.; Velizarov, S.; Coelhoso, I. A novel cellulose-based polymer for efficient removal of methylene blue. Membranes 2020, 10, 13. [CrossRef] [PubMed]

82. Muthanna, J.A.; Samar, K.D. Equilibrium isotherms and kinetics modeling of methylene blue adsorption on agricultural wastesbased activated carbons. Fluid Phase Equilib. 2012, 317, 9-14.

83. Ponnusami, V.; Vikram, S.; Srivastava, S.N. Guava (Psidium guajava) leaf powder: Novel adsorbent for removal of methylene blue from aqueous solutions. J. Hazard. Mater. 2008, 152, 276-286. [CrossRef] [PubMed]

84. Mosoarca, G.; Vancea, C.; Popa, S.; Gheju, M.; Boran, S. Syringa vulgaris leaves powder a novel low-cost adsorbent for methylene blue removal: Isotherms, kinetics, thermodynamic and optimization by Taguchi method. Sci. Rep. 2020, 10, 17676. [CrossRef] [PubMed]

85. Jawad, A.H.; Rashid, R.A.; Mahmuod, R.M.A.; Ishak, M.A.M.; Kasim, N.N.; Ismail, K. Adsorption of methylene blue onto coconut (Cocos nucifera) leaf: Optimization, isotherm and kinetic studies. Desalination Water Treat. 2015, 57, 8839-8853. [CrossRef]

86. Krishni, R.R.; Foo, K.Y.; Hameed, B.H. Adsorptive removal of methylene blue using the natural adsorbent-banana leaves. Desalination Water Treat. 2014, 52, 6104-6112. [CrossRef]

87. Gupta, N.; Kushwaha, A.K.; Chattopadhyaya, M.C. Application of potato (Solanum tuberosum) plant wastes for the removal of methylene blue and malachite green dye from aqueous solution. Arab. J. Chem. 2016, 9, S707-S716. [CrossRef]

88. Bhattacharyya, K.G.; Sharma, A. Kinetics and thermodynamics of methylene blue adsorption on neem (Azadirachta indica) leaf powder. Dyes Pigm. 2005, 65, 51-59. [CrossRef]

89. Loulidi, I.; Boukhlifi, F.; Ouchabi, M.; Amar, A.; Jabri, M.; Kali, A.; Chraibi, S.; Hadey, C.; Aziz, F. Adsorption of crystal violet onto an AgriculturalWaste Residue: Kinetics, isotherm, thermodynamics, and mechanism of adsorption. Sci. World. J. 2020, 2020, 5873521. [CrossRef]

90. Jiang, Z.; Hu, D. Molecular mechanism of anionic dyes adsorption on cationized rice husk cellulose from agricultural wastes. J. Mol. Liq. 2019, 276, 105-114. [CrossRef]

91. Zhai, Q.-Z. Studies of adsorption of crystal violet from aqueous solution by nano mesocellular foam silica: Process equilibrium, kinetic, isotherm, and thermodynamic studies. Water Sci. Technol. 2020, 81, 2092-2108. [CrossRef] [PubMed]

92. Gerçel, O.; Özcan, A.; Özcan, A.S.; Gerçel, H.F. Preparation of activated carbon from a renewable bio-plant of Euphorbia rigida by $\mathrm{H}_{2} \mathrm{SO}_{4}$ activation and its adsorption behavior in aqueous solutions. Appl. Surf. Sci. 2007, 253, 4843-4852. [CrossRef]

93. Soldatkina, L.; Yanar, M. Equilibrium, kinetic, and thermodynamic studies of cationic dyes adsorption on corn stalks modified by citric acid. Colloids Interfaces 2021, 5, 52. [CrossRef]

94. Fathy, N.A.; El-Shafey, O.I.; Khalil, L.B. Effectiveness of alkali-acid treatment in enhancement the adsorption capacity for rice straw: The removal of methylene blue dye. Phys. Chem. 2013, 2013, 208087. [CrossRef]

95. Namasivayam, C.; Muniasamy, N.; Gayatri, K.; Rani, M.; Ranganathan, K. Removal of dyes from aqueous solutions by cellulosic waste orange peel. Bioresour. Technol. 1996, 57, 37-43. [CrossRef]

96. Venkata Mohan, S.; Chandrasekhar Rao, N.; Karthikeyan, J. Adsorptive removal of direct azo dye from aqueous phase onto coal based sorbents: A kinetic and mechanistic study. J. Hazard. Mater. 2002, 90, 189-204. [CrossRef] 